\title{
Multiproduct Firms, Firm Dynamics, and the Productive Mix of Brazilian Manufacturing Firms
}

\author{
Juliana Dias Alves ${ }^{1}$ \\ Mauro Sayar Ferreira ${ }^{2}$
}

\begin{abstract}
This paper studies the Brazilian manufacturing sector in line with the literature on heterogeneous firm. We focus i) on the characteristics of firms that are multi-product (MP), multi-sector and multi-industry; and ii) on the analysis of their scope, including the determinants of product switching, behavior over business cycle, and relation with several firm's characteristics. MP corresponds to $37 \%$ of all manufacturing firms, but generates $81 \%$ of the output. They employ more workers, are more likely to be exporters, have higher labor productivity and higher TFP. The extensive margin due to adding and retirement of products contributes more to output growth than entry and exit of firms. All margins are positive correlated to GDP growth: the intensive margin has an almost perfect correlation, followed by the product margin, with values around 0.91 , and then by firm's margin, with correlations around 0.60 . When restricting the study to continuing firms, it was found that half of the annual output growth (from 2005 to 2009) was originated by firms that switched products. Those that have net added (dropped) items had higher (smaller) increase in output, in employees, and in the TFP. Having higher TFP, more employees, or being an exporter increase the probability of only adding or only dropping items in the future.
\end{abstract}

\section{Keywords}

Multiproduct. Scope. Total factor productivity. Heterogeneous firms. Extensive margin. Intensive margin. Export.

- This work is part of the Doctoral thesis of Juliana Dias Alves, defended in 2015 at the Universidade Federal de Minas Gerais. We would like to thank Naércio Menezes, Mauro Rodrigues Jr., and the anonymous referee for valuable comments and suggestions. We also thank Antonio Braz for his valuable help on how to deal with the dataset and several other discussions. As usual, all errors are our own fault.

1 Economista - Instituto Brasileiro de Geografia e Estatística (IBGE)

Endereço: Rua Oliveira, 523 - Cruzeiro - Belo Horizonte/MG - Brasil - CEP: 30310-150

E-mail: juliana.alves@ibge.gov.br - https://orcid.org/0000-0003-3236-2762

2 Professor - Universidade Federal de Minas Gerais (UFMG)

Endereço: Av. Antonio Carlos, 6627 - Pampulha - Belo Horizonte/MG - Brasil

CEP: 31270-901 - E-mail: mferreira@cedeplar.ufmg.br - https://orcid.org/0000-0003-2865-2281

Recebido: 22/03/2017. Aceite: 30/10/2017

Esta obra está licenciada com uma Licença Creative Commons Atribuição-Não Comercial 4.0 Internacional. 


\section{Resumo}

Este artigo analisa a indústria manufatureira no Brasil na perpsectiva da literatura de firmas heterogêneas. A análise focou i) nas características das firmas multi-produto (MP), multi-setor e multi-indústria; e ii) no escopo das firmas, incluindo os determinantes da alteração de produtos, comportamento ao longo do ciclo econômico, e relação com demais características de cada empresa. Firmas do tipo MP representam 37\% do total, mas geram $81 \%$ do valor da produção (VP). Elas empregam mais funcionários, têm maior probabilidade de serem exportadoras, maior produtividade do trabalho e maior produtividade total dos fatores (PTF). A margem extensiva proveniente da adição e retirada de produtos do leque produtivo contribui mais para o crescimento do VP do que o movimento de entrada e saída de firmas do mercado. Todas as margens correlacionam-se positivamente com o crescimento do PIB: a margem intensiva apresenta correlação quase perfeita, seguida pela margem de produto, com valores em torno de 0,91 , e depois pela margem das firmas, cuja correlação ficou em torno de 0,60. Ao analisar as firmas sobreviventes, metade do crescimento do VP (de 2005 a 2009) teve origem naquelas que promoveram algum tipo de alteração no escopo produtivo. As firmas que adicionaram (retiraram) produtos ao (do) leque de produção obtiveram maior (menor) crescimento do VP, do número de empregados e da PTF. Firmas com maior PTF, com mais trabalhadores e as exportadoras têm maior probabilidade de somente adicionar ou somente retirar produtos do seu escopo produtivo.

\section{Palavras-Chave}

Multiproduto. Escopo. Produtividade total dos fatores. Firmas Heterogêneas. Margem extensiva. Margem intensiva. Firmas exportadoras.

\section{Classificação JEL}

D2. F23. L1. L16. L6.

\section{Introduction}

This is a pioneer study about the productive scope of the Brazilian manufacturing sector in line with the literature on heterogeneous firm proposed mainly by Bernard, Redding and Schott (2010) [BRS (2010), henceforth], BRS (2011) and Eckel and Neary (2010). These works incorporate product heterogeneity among multiproduct plants in the set up that has been developed by Melitz (2003), Bernard et al. (2003), Melitz e Ottaviano (2008), among others.

Melitz (2003), Bernard et al. (2003), and Melitz and Ottaviano (2008) emphasized the relevance of entry and exit of firms for resource allocation within an economy. This movement, which we refer throughout this paper as extensive margin 1 (or simply EXl), would raise aggregate productivity by liberating resources from least efficient firms to most efficient ones. 
BRS (2010) added the possibility of adjustments in the productive mix inside each firm. Specifically, surviving firms can manufacture new varieties and/or drop old ones. Specializing in items they can manufacture more efficiently contribute to a better use of resources in an economy. This product extensive margin, which we refer to as extensive margin 2 (EX2, henceforth), has not deserved the appropriate attention previously, despite the fact that approximately $50 \%$ of U.S. manufacturing firms conducts some change in scope within at least a 5-year interval (BRS, 2010).

\section{Main Results}

From 2005 to 2009, only 37\% of the firms in the Brazilian manufacturing sector were multiproduct, but they were responsible for $81 \%$ of total output. They employed more workers, were more likely to be exporters, had higher labor productivity and higher total factor productivity.

Using a product decomposition proposed by BRS (2010), an average of $86 \%$ of aggregate output was due to products manufactured by the same firm (intensive margin) in previous period; $8.5 \%$ from varieties produced by surviving firms that did not produce the item in previous year (EX2); and the remaining 5.5\% from the traditional extensive margin (EXl).

The literature still lacks a good body of stylized facts regarding the business cycle contribution of these margins. By decomposing the output growth through the years new evidences were provided to help in this direction. The intensive margin contributed with $76.2 \%$ of the output increase from 2005 to 2009; product margin from established firms with 14.9\%, and traditional extensive margin (EXl) with 8.9\%. During the financial crisis of 2008/2009, the total output fell by $15.88 \%$ : variation in the intensive margin was $-15.31 \%$, in EX2 was $-0.05 \%$, and in EX1 was $-0.52 \%$.

The annual growth of these margins correlate with the annual growth rate of GDP, manufacturing GDP, and investment. Correlations between the intensive margin growth and growth in NIPA aggregates were all close to 1. Variation in product margin came in second, with correlations varying from 0.89 to 0.93 , while firms's margin growth came in the last position, with correlations ranging from 0.52 to 0.65 . 
Since we were particularly interested in studying firms that changed scope, the entire section 6 was dedicated to analyze surviving firms. Among this group, $62.7 \%$ promoted at least one change in the productive scope from 2005 to 2009, contributing with $73.4 \%$ of the total output divided as follows: $47.4 \%$ by firms that added and dropped varieties, $13.9 \%$ by those that only added, and $12.1 \%$ by only droppers. Exporters contributed more to output among surviving firms. Exporters and larger firms (top decile in terms of output) were more likely to modify scope.

Evaluating the output growth among surviving firms, in a similar exercise conducted by Navarro (2012) for the Chilean manufacturing sector, it was found that approximately $50 \%$ of product increase was generated by firms that conducted some change in the productive mix. Among them, the most important contribution came from firms that manufactured more items.

The last exercise aimed at verifying the determinants of changes in scope among surviving firms. Larger firms (by number of employees) and exporters were more likely to either add or drop items from their productive mix, compared to those that did not modify their scope. Firms with higher TFP were less likely to only add or only drop varieties.

\section{Related Literature}

The theoretical development of BRS (2010), BRS (2011) and Eckel and Neary (2010) adds, to the heterogeneous firm environment, multiproduct plants and consumers with stronger preference over some varieties, which allow demand shocks to influence results. Given preferences, most productive firms would produce more varieties since they can afford paying for fixed costs associated to the production of each extra item. According to BRS (2010), this prediction of the model helps to explain the stylized fact that most productive plants tend to produce more varieties.

Eckel and Neary (2010) present a model with multiproduct plants in which global competition and demand play combined roles in determining firm's scale and scope in equilibrium. From the demand side, the introduction of new varieties to satisfy heterogeneous tastes reduces the demand 
for existing products. The continuum of varieties would be supplied by several firms, each having a "core competence" in which certain products would be manufactured more efficiently. The further away from this center, the higher the marginal cost to produce the item. The productive mix would then depend on the degree of competition for each item, on consumers' preference, and on the relation between "excellence core" and marginal cost of each variety. International competition may then result in higher aggregate TFP by forcing firms to produce varieties closer to their competence core, but can also result in fewer items produced by a country.

BRS (2011), based on Mayer, Melitz e Ottaviano (2010), also shows that multiproduct firms would tend to obtain higher revenue from items closer to their excellence core, since productivity and quality would decline as new varieties are manufactured. Arkolakis and Muendler (2010) further observed that, in the presence of entry cost per each new variety supplied, larger and more efficient plants would produce more output and varieties, resulting in positive correlation between extensive and intensive margins within a firm.

Nocke and Yeaple (2006) do not use the notion of competence core of products, but allow firms to have distinguished organizational capacity, which determines the rate at which the marginal cost of an extra variety increases. Better managerial skills would result in smaller marginal cost, implying greater variety. In line with these theoretical predictions, Iacovone and Javorcik (2010) documented, for Mexico, that products more distant from the excellence core had higher probability of being dropped from the productive mix following the country's entry in NAFTA.

Besides the work of BRS (2010) for the USA, to our knowledge only a few other countries have had their manufacturing sector studied in the lines proposed by the theoretical development just cited: Navarro (2012) for Chile, Goldberg et al (2010) for India, Elliot and Virakul (2008) for Thailand, Bernard and Okubo (2013) for Japan, and Söderbom and Weng (2012) for China. For Brazil, Arkolakis and Muendler (2010) is the closest reference, but they were mostly interested in verifying the exporting mix of the Brazilian manufacturing firms. Conclusions were all in line with theoretical predictions. Multiproduct plants tend to be more productive, have more workers, and are more likely to be exporters than single product firms. 
Besides this introduction, the rest of this work is organized as follows. Next section presents data and explains the procedures to allow combining two microdata record we work with: Annual Survey of Industry - Product (PIA Product), and the Annual Survey of Industry - Enterprise (PIA Enterprise). ${ }^{l}$ Section 3 characterizes data according to the contribution of each item to output according to the amount of varieties produced by each group of firm. We also show the relevance of MP, MI, and MS firms, in terms of their presence and their contribution to production. In section 4 we are able to empirically corroborate some predictions of BRS (2010, 2011) and Eckel and Neary (2010) by verifying differences between MP, MI, and MS against their single counterparts. Later, in section 5 , we decompose production and analyze the contribution of the intensive margin and two extensive margins to output production and output growth. Correlation between these margins' growth rate and NIPA aggregates growth rates is also estimated, generating interesting business cycle stylized facts. Section 6 studies only surviving firms in an attempt to focus on their strategies towards productive mix and how such strategies are related to firm's performance. Section 7 concludes.

\section{Data}

Our work was only possible because we connected, at firm level, two different surveys conducted by the Brazilian Institute of Geography and Statistics (IBGE). The first, called Annual Survey of Industry-Product (PIA-Product), surveys the plants of every manufacturing firm with 30 or more employees and/or that had gross revenue above a certain threshold in the preceding year of the survey. For each firm, it informs the amount produced, production value, and revenue from each product and

1 Important to mention that Esteves (2015) has also conducted a study for Brazil using information from PIA - Product. He estimated production stochastic frontier models to obtain a technical efficient index of each product. Esteves also verified that being a multiproduct plant resulted, for most plants, in less output, suggesting that greater specialization would enhance production in such plants. His work did not advance to explore further results nor brought stylized facts in line with the literature on heterogenous firms and trade. He neither tried to verify further relations between scope and plant's characteristics, which is an issue we extensively study in the current work. So, despite using similar data, which allowed Esteves to verify the indication that several plants would achieve higher output by reducing their productive scope, his work did not advance in exploring other results and relations in line with actual theoretical advances in the area. 
service. These products and industrial services, which encompass around 3,500 different items, were classified according to the List of Industrial Products ${ }^{2}$ (PRODLIST-Industry), following the Common Classification of MERCOSUR (NCM), and presented by classes of the National Standard Industrial Classification of All Economic Activities (CNAE 2.0). PIAProduct started in 1998, but microdata only became available as of 2005.

Table 1 - Number of products in 2005 and 2009, absolute variation, and number of industries in 2009. According to four digits CNAE 2.0

\begin{tabular}{lcccc}
\hline \multicolumn{1}{c}{ Sector } & $\begin{array}{c}\text { N.․ products } \\
\text { (2005) }\end{array}$ & $\begin{array}{c}\text { N.․ products } \\
\text { (2009) }\end{array}$ & $\begin{array}{c}\text { Absolute } \\
\text { variation }\end{array}$ & $\begin{array}{c}\text { N.․ industries } \\
\text { (2009) }\end{array}$ \\
\hline Food products & 301 & 310 & 9 & 31 \\
Beverages & 29 & 28 & -1 & 5 \\
Tobacco products & 7 & 7 & 0 & 2 \\
Textiles & 138 & 147 & 9 & 14 \\
Wearing apparel & 87 & 89 & 2 & 6 \\
Leather and related products & 69 & 71 & 2 & 8 \\
Wood, products of wood and cork, except furniture; articles & & & & \\
of straw and plaiting materials & 44 & 44 & 0 & 5 \\
Paper and paper products & 84 & 87 & 3 & 9 \\
Printing and reproduction of recorded media & 41 & 52 & 11 & 6 \\
Coke and refined petroleum products & 38 & 40 & 2 & 5 \\
Chemicals and chemical products & 445 & 439 & -6 & 25 \\
Basic pharmaceutical products and pharmaceutical & & & & \\
preparations & 95 & 89 & -6 & 4 \\
Rubber and plastics products & 114 & 118 & 4 & 7 \\
Other non-metallic mineral products & 113 & 111 & -2 & 11 \\
Basic metals & 105 & 113 & 8 & 14 \\
Metal products, except machinery and equipment & 196 & 199 & 3 & 16 \\
Computer, electronic and optical products & 154 & 161 & 7 & 11 \\
Electrical equipment & 133 & 133 & 0 & 10 \\
Machinery and equipment n.e.c. & 368 & 374 & 6 & 26 \\
Motor vehicles, trailers and semi-trailers & 82 & 84 & 2 & 10 \\
Other transport equipment & 51 & 55 & 4 & 10 \\
Furniture & 69 & 70 & 1 & 4 \\
Other manufacturing & 132 & 139 & 7 & 9 \\
Repair and installation of machinery and equipment & 39 & 54 & 15 & 10 \\
\hline Total & 2934 & 3014 & 80 & 258 \\
\hline & & & & \\
\hline
\end{tabular}

Source: PIA-Product and PIA-Enterprise (IBGE).

2 PRODLIST-Industry is a classification used by the Brazilian Institute of Geography and Statistics (IBGE). 
The second database is the Annual Survey of Industry - Enterprise (PIAEnterprise). It provides information about the number of employees, wages and salaries, revenue and expenses, production cost and gross value added. The survey unit corresponds to enterprises with 10 or more employees and/or whose gross revenue surpassed a certain threshold in the previous year of the survey. The period ranging from 1996 to 2007 was originally classified according to the previous industrial classification, CNAE 1.0. From 2007 to 2009, ${ }^{3}$ classification was according to CNAE 2.0. Since our estimates use data from before and after 2007, the correspondence between both classifications were investigated and every pre-2007 product information was recoded according to CNAE 2.0.

So, while PIA-Product provides a panel of firms with the production value of each product and service, classified according to the Prodlist, PIAEnterprise characterizes several dimensions of each firm at four digits CNAE. The connection of both surveys allows analysis at firm and product level.

Production value of each item was deflated by a specific price index. These deflators were obtained from the Supply and Use Tables (TRU), which is part of the System of National Accounts (SNC), after establishing a correspondence between activities in SNC and CNAE 2.0. ${ }^{4}$

Table 1 provides a summary of sectors, industries, and products. A total of 3,014 items were produced in 2009 and 2,934 in 2005. In absolute terms, larger increases in the number of varieties were observed in the following sectors: food products (10), textiles (13), printing and reproduction of recorded media (18), basic metals (24), repair and installation of machinery and equipment (33).

2009 was the last year in which the survey was available when our exercises were being conducted.

4 Table A.1 in appendix. 


\section{Characterizing the Data}

We started characterizing the data by verifying how the production value is distributed among varieties produced by each firm. Table 2 presents the average share of revenue originated by each good after controlling the number of varieties produced. ${ }^{5}$ The columns show the number of varieties manufactured by a firm, which can be 1, 2, and so on. Any firm producing 10 or more goods was pooled in the last column $(\geq 10)$. A specific row informs the average contribution of a product to the total revenue of a "representative" firm producing the number of items indicated in the specific column. For instance, among firms producing only 2 items, the contribution of a single good for the total revenue was, on average, $75 \%$, while the remaining $25 \%$ would come from the second good. Firms producing 9 items concentrate, on average, $45 \%$ of their revenue on only one item and another $20 \%$ on a second variety. The remaining $35 \%$ is divided among the other 7 products, also in a disproportionate manner.

As comparison, BRS (2010) reported that US manufacturing firms producing only two goods, had, on average, $80 \%$ of the revenue generated by one of them, against $75 \%$ we found for Brazil. They also verified that among those producing 10 or more items, the average contribution of the main product was $46 \%$, almost identical to the $45 \%$ we observed for Brazil. These results are also very similar to the patterns reported by Goldberg et al. (2010), Navarro (2012) and Söderbom and Weng (2013), when analyzing Mexico, Chile and China, respectively.

The overall finding for Brazil is that, on average, few items contribute with a very large fraction of the total output of each manufacturing firm. This is in line with the developments of BRS (2010) and Eckel and Neary (2010) for whom each firm has better performance in products closer to their excellence core, resulting in a distribution of revenue skewed in a way that some varieties are responsible for a greater share of the revenue. ${ }^{6}$

5 The variable used was output value, taken from PIA-Product.

6 Nocke and Yeaple (2006) provide a different perspective: there are not differences within a firm associated to the production of any specific good, and managerial skills would determine the amount of varieties produced by each firm. As a result, one should observe an even distribution of revenue from different varieties. 
Table 2 - Average share (\%) in output originated by each good given the number of varieties produced. Period: 2005 and 2009

\begin{tabular}{|c|c|c|c|c|c|c|c|c|c|c|}
\hline \multirow[b]{2}{*}{$\begin{array}{l}\text { Importance } \\
\text { rank in output } \\
\text { production }\end{array}$} & \multicolumn{10}{|c|}{ Number of varieties produced by each firm } \\
\hline & 1 & 2 & 3 & 4 & 5 & 6 & 7 & 8 & 9 & $\geq 10$ \\
\hline 1st & 1.00 & 0.75 & 0.64 & 0.58 & 0.54 & 0.50 & 0.49 & 0.46 & 0.45 & 0.45 \\
\hline 2nd & & 0.25 & 0.25 & 0.24 & 0.23 & 0.22 & 0.21 & 0.21 & 0.20 & 0.20 \\
\hline $3 r d$ & & & 0.11 & 0.12 & 0.12 & 0.12 & 0.12 & 0.12 & 0.12 & 0.12 \\
\hline 4th & & & & 0.06 & 0.07 & 0.08 & 0.08 & 0.08 & 0.08 & 0.08 \\
\hline 5 th & & & & & 0.04 & 0.05 & 0.05 & 0.05 & 0.06 & 0.05 \\
\hline 6th & & & & & & 0.03 & 0.03 & 0.04 & 0.04 & 0.04 \\
\hline 7 th & & & & & & & 0.02 & 0.02 & 0.03 & 0.03 \\
\hline 8th & & & & & & & & 0.01 & 0.02 & 0.02 \\
\hline 9th & & & & & & & & & 0.01 & 0.01 \\
\hline 10th & & & & & & & & & & 0.01 \\
\hline
\end{tabular}

Source: PIA-Product (IBGE), 2005 and 2009. Authors' computation.

In Table 3 we report general information about the composition of manufacturing firms according to their classification as multiproduct (MP), multi-industry (MI) and multisector (MS), in 2009. ${ }^{7}$ These classifications followed BRS (2010). Single product (SP) firms are those whose range of products falls within a single five-digit category in Prodlist. Multiproduct (MP) is one whose product range is wide enough to span several five-digit of Prodlist categories. Multi-industry (MI) has products classified in more than one CNAE in four digits, while multisector (MS) has products in more than one division (two digits of the CNAE).

Despite differences in dates and product classification, we also report information for countries in which similar exercise has been conducted $^{8}$ (EUA, India, Chile, Japan and China). Panel A reveals that $37 \%$ of Brazilian manufacturing firms produced more than one variety in $2009,23 \%$ operated in more than one industry and $13 \%$ in more than one sector. The USA came closer regarding MP, with $41 \%$ of the firms producing more than one variety.

\footnotetext{
7 We decided to report results for the last year available at the time this work was being elaborated. However, values for 2005, 2006, 2007 and 2008 are all very similar.

8 Table A.1 in appendix.
} 
Panel B shows that MP firms were responsible for $81 \%$ of the output, a proportion similar to those reported for India and Japan. Panel C shows the average number of product per MP firm, the average number of industry each MI firm participates, and the average number of sectors each MS firm belongs to. Brazilian MP firms produced, on average, 3.8 items each, close to Chile (3.9) and the US (4.0). Each MI firm belonged to an average of 2.9 industries, and each MS firm participated, on average, in 2.4 sectors.

Table 3 - The relevance of firms MP, MI, and MS: percentage of firms, contribution to output, average number of varieties, industry, and sector: USA, India, Chile, China, Japan, and Brazil

\begin{tabular}{c|ccc|cccc}
\hline \multirow{2}{*}{ Type of firm } & USA & India & Chile & Japan & China & Brazil \\
\cline { 2 - 7 } & \multicolumn{7}{c}{ Panel A - Percentage of firms (\%) } \\
\hline MP & 41 & 47 & 52 & 41 & 47 & 37 \\
MI & 29 & 33 & 22 & 31 & 34 & 23 \\
MS & 13 & 24 & 9 & 17 & 9 & 13 \\
\hline \multirow{2}{*}{ MP } & 91 & 80 & 56 & 78 & 50 & 81 \\
MI & 87 & 62 & 23 & 70 & 43 & 70 \\
MS & 76 & 54 & 8 & 51 & 25 & 50 \\
\hline \multirow{2}{*}{ MP } & 4.0 & 3.1 & 3.9 & 2.7 & 2.8 & 3.8 \\
MI & 3.1 & 2.0 & 2.6 & 2.9 & 2.3 & 2.9 \\
MS & 2.5 & 1.7 & 2.2 & 3.1 & 2.1 & 2.4 \\
\hline
\end{tabular}

Source: PIA-Product (IBGE), 2009. Other countries: see literature review in the introduction.

* The variable used for this analysis varies among articles. In our case we used the output value informed in PIA- Product, 2009.

\section{Differences between Multiproduct, Multi-industry, and Multisector}

Given that MP was responsible for $81 \%$ of the total manufacturing output, it seems natural to verify whether this group has characteristics that differ them from single product firms. As emphasized in the introduction, theoretical predictions of BRS $(2010,2011)$ and Eckel and Neary (2010) indicate that MP firms should be larger, more productive and produce more output. These characteristics make them more likely to be exporters. We will now verify these conjectures. 
Let $Z_{j i}$ be a specific characteristic of firm $j$ belonging to sector $i$. We want to verify whether characteristic $Z$ is correlated to the fact that a firm is MP, MI and MS. These comparisons are carried after estimating the regression model

$$
Z_{j i}=\mu D_{j i}^{h}+F_{i}+\varepsilon_{j}
$$

and testing $H_{0}: \mu=0$ against $H_{1}: \mu \neq 0$. In the previous equation, $h$ indexes firm's characteristic: $h=\{S P, M P, S I, M I, S S, M S\} . D_{j i}^{h}$ is a dummy variable such that $D_{j i}^{h}=1$ if $h=\{M P, M I, M S\}$ and $D_{j i}^{h}=0$ otherwise. $F_{i}$ is a fixed effect for each sector, and $\varepsilon_{j}$ captures random characteristics of firm $j$ which are independent across firms. For each pair of possibility (SP or MP; SI or MI; SS or MS), one regression is estimated. We considered the following characteristics: $Z=\{$ logarithm of output value, logarithm of number of employees, a dummy that equals 1 in case a firm is an exporter and 0 if not, labor productivity, ${ }^{9}$ logarithm of the total factor productivity $\left.(\mathrm{TFP})^{10}\right\}$. Results are in Table 4.

Positive and significant $\mu$ was verified in all cases, indicating that MP, MI and MS have, on average, higher values of all variables $Z$ when contrasted to SP, SI, SS, respectively. These results corroborate theoretical predictions. Specifically, when confronted against SP, it was verified that MP firms produced, on average, 8\% more output value, and employed $10 \%$ more workers that were $4 \%$ more productive. They also had higher TFP.

Compared to SI firms, MI generated, on average, 6\% more output, employed $8 \%$ more workers that were $3 \%$ more productive. Confronting against SS firms, MS generated 4\% more output and employed 6\% more workers who were $2 \%$ more productive. In all cases, TFP was higher in $\mathrm{MI}$ and $\mathrm{MS}^{11}$

9 Labor productivity is measured as the logarithm of output per number of employers.

${ }^{10}$ TFP of each firm was estimated from 2005 to 2009 according to Olley and Pakes (1996) and Levinsohn and Petrin (2003). For more details, see the appendix and Alves and Ferreira (2013).

${ }^{11}$ Our results are difficult to compare to those of Esteves (2015), since the author did not analyze the output of each firm, but of each plant. He verified that most multiproduct plants had smaller output. 
Table 4 - Relationship of MP, MI, and MS with output, number of employees, exporting status, labor productivity, and TFP. Brazil, 2005-2009

\begin{tabular}{|c|c|c|c|}
\hline Characteristics & MP & MI & MS \\
\hline $\operatorname{Ln}$ (output) & $0.08^{* * *}$ & $0.06^{\star * *}$ & $0.04^{\star \star *}$ \\
\hline Ln(n.employees) & $0.10^{\star \star *}$ & $0.08^{\star \star *}$ & $0.06^{\star \star *}$ \\
\hline Exporter ( 1 if yes) & $0.23^{\star \star *}$ & $0.19^{\star * *}$ & $0.14^{* * *}$ \\
\hline Ln(output/employee) & $0.04^{\star \star *}$ & $0.03^{\star \star *}$ & $0.02^{\star \star \star}$ \\
\hline $\operatorname{Ln}(T F P)$ & 0.00 ** & $0.00^{* *}$ & $0.00^{* *}$ \\
\hline
\end{tabular}

Source: PIA-Product (IBGE), 2005 and 2009. Authors' computation.

Note: Reported values correspond to estimated coefficient $\mu$ of Equation 1: $Z_{j i}=\mu D_{j i}^{h}+F_{i}+\varepsilon_{j}$. Characteristics in the $1^{\text {st }}$ column correspond to variables $Z$. $F_{i}$ are sector fixed effects. Significance: $* \star *$ $1 \%, * * 5 \%$ and $* 10 \%$. Number of observations: 159,717 .

Regarding their presence in the international market, MP was 23\% more likely of being an exporter than SP. MI had 19\% higher probability of being an exporter than SI, and MS was 14\% more likely to be and exporter than SS.

\section{Output Decomposition: Extensive and Intensive Margin}

We have just verified that, in $2009,81 \%$ of the output was generated by MP firms. Next, the relevance of the intensive margin, product margin (EX2) and plant margin (EX1) in total production and in production growth is assessed.

\subsection{Contribution to Output}

We follow Bernard and Okubo (2013) who suggested decomposing the output of each product by the type of firm producing it. This allows verifying the proportion of output due to each margin.

Let's consider $Y_{p, t / t-h}$ as the production of good $p$ at time $t$ according to firm's status in $t$-h. A firm producing $Y$ at time $t$ could have been of any following type in $t$ - $h$ : a surviving firm that produced good $p$ in $t-h$ and in $t$ (group B); a surviving firm that added $Y$ to the production mix at time $t$ (group A); or a new firm, inexistent at $t$ - $h$, that produced good $p$ at time 
$t$ (group $\mathrm{N}$ ). Considering $j$ as the index of an individual firm, this decomposition can be represented as follows:

$$
Y_{p, t / t-h}=\sum_{j \in B_{p}} Y_{p, t / t-h}^{j}+\sum_{j \in A_{p}} Y_{p, t / t-h}^{j}+\sum_{j \in N_{p}} Y_{p, t / t-h}^{j}
$$

In a second decomposition, the production of $p$ at time $t$ was divided according to the firm's status at $t+h\left(Y_{p, t / t+h}\right)$. As previously, a surviving firm manufacturing $Y_{p}$ at $t$ and $t+h$ belongs to B. A surviving firm producing $Y_{p}$ in $t$ but no longer in $t+h$ belongs do D. Firms manufacturing $Y_{p}$ at $t$ but that left the market in $t+h^{12}$ belong to group $\mathrm{X}$. This decomposition works as follows:

$$
Y_{p, t+h / t}=\sum_{j \in B_{p}} Y_{p, t / t+h}^{j}+\sum_{j \in D_{p}} Y_{p, t / t+h}^{j}+\sum_{j \in X_{p}} Y_{p, t / t+h}^{j}
$$

Columns 2 to 4 of Table 5 report the backward decomposition (Equation 2), while the last three columns inform the forward decomposition (Equation 3). Panel A presents the share of each group in aggregate output, while panel $\mathrm{B}$ shows the proportion of firms in each group. We considered years 2005, 2007 and 2009, so that $h=2$.

Backward (forward) results indicate that $86-87 \%$ of the output was generated by products manufactured by the same firm in $t-2(t+2)$. Items produced by continuing firms that have added (dropped) them were responsible for $8-9 \%(7-9 \%)$ of the total output, slightly superior to items made by new firms (5-6\%) or by those that died (6\%). ${ }^{13}$ Our results are very similar to those of Bernard and Okubo (2013) for Japan.

In Panel B the proportion of firms belonging to each group is verified. Around $58 \%$ belonged to $\mathrm{B}$, producing the same product in two consecutive years. Surviving firms that added and dropped products represented $22 \%-25 \%$ of the firms investigated. Inexistent firms and those that left the market ranged from $16 \%$ to $21 \%$ of the total.

12 These decompositions have the advantage that results can be easily transformed into percentage variations, with no need for deflating.

${ }^{13}$ One can argue that entrants may arrive with enormous innovation potential and may become major player in the future. However, our notion of "importance" only refers to the percentage of output generated. As more years of survey become available, it will become possible to evaluate the performance of these entrants against established firms. 
Table 5 - Product-Level Decomposition of output: 2005, 2007 and 2009

\begin{tabular}{c|c|c|c|c|c|c}
\hline \multirow{2}{*}{ Year (t) } & \multicolumn{2}{|c|}{ Backward looking (Equation 2) } & \multicolumn{3}{c}{ Forward looking (Equation 3) } \\
\cline { 2 - 7 } & $\begin{array}{c}\text { Plants } \\
\text { producing } \\
\text { the item in } t \\
\text { and } t-2 \text { (B) }\end{array}$ & $\begin{array}{c}\text { Plants adding } \\
\text { the item } \\
\text { between } t-2 \\
\text { and } t(\mathrm{~A})\end{array}$ & $\begin{array}{c}\text { Plants born } \\
\text { between } t-2 \\
\text { and } t(\mathrm{~N})\end{array}$ & $\begin{array}{c}\text { Plants } \\
\text { producing the } \\
\text { item in } t \text { and } \\
t+2 \text { (B) }\end{array}$ & $\begin{array}{c}\text { Plants dropping } \\
\text { the item } \\
\text { between } t \text { and } \\
t+2(\mathrm{D})\end{array}$ & $\begin{array}{c}\text { Plants that die } \\
\text { between } t \text { and } \\
t+2(\mathrm{X})\end{array}$ \\
\hline \multicolumn{7}{c}{ Panel A. Output share (\%) } \\
\hline 2005 & - & - & - & 86 & 9 & 6 \\
2007 & 86 & 9 & 6 & 87 & 7 & 6 \\
2009 & 87 & 8 & 5 & - & - & - \\
\hline \multicolumn{7}{c}{ Panel B. Plants share (\%) } \\
\hline 2005 & - & - & 58 & 25 & 18 \\
2007 & 56 & 24 & 20 & 60 & 24 & - \\
\hline
\end{tabular}

Source: PIA-Product (IBGE), 2005, 2007, and 2009. Authors' computation.

Note: The first three columns show decomposition according to $Y_{p, t / t-h}=\sum_{j \in B_{p}} Y_{p, t / t-h}^{j}+\sum_{j \in A_{p}} Y_{p, t / t-h}^{j}+\sum_{j \in N_{p}} Y_{p, t / t-h}^{j}$, where $Y_{p, t / t-h}$ is the production of good $p$ at time $t$ according to firm's status in $t$ - $h$. Each firm $j$ producing product $p$ at time $t$ has status $\mathrm{B}, \mathrm{A}$ or $\mathrm{N}$, whose definitions are in the top of each column. The last three columns decompose products according to $Y_{p, t / t+h}=\sum_{j \in B_{p}} Y_{p, t / t+h}^{j}+\sum_{j \in D_{p}} Y_{p, t / t+h}^{j}+\sum_{j \in X_{p}} Y_{p, t / t+h}^{j}$, where $Y_{p, t / t-h}$ is the production of good $p$ at time $t$ according to firm's status in $t+h$. Each firm $j$ producing product $p$ at time $t$ has status $\mathrm{B}, \mathrm{D}$ or $\mathrm{X}$, whose definitions are at the top of each column.

\subsection{Contribution to Growth}

The decomposition suggested by BRS(2010) was conducted next in order to verify the contribution of each margin to the total output growth. Variation in output from year $t$ - $h$ to year $t\left(\Delta Y_{t}\right)$ could be due to: (i) two extensive margins, the first resulting from net entry of new firms (EX1, plant margin), and the second from net addition of items by continuing firms (EX2, product margin); and (ii) the intensive margin (INT) determined by net growth in the output of items already produced by continuing firms.

$$
\Delta Y_{t}=\sum_{j \in N} \Delta Y_{j t}+\sum_{j \in X} \Delta Y_{j t}+\sum_{j \in B}\left[\sum_{i \in S} \Delta Y_{i j t}+\sum_{i \in G} \Delta Y_{i j t}+\sum_{i \in A} \Delta Y_{i j t}+\sum_{i \in D} \Delta Y_{i j t}\right]
$$


In Equation 4, $j$ indexes the following status: new firm $(N)$, firm that left the market $(X)$, or a surviving firm $(B)$. The terms $\sum_{j \in N} \Delta Y_{j t}$ and $\sum_{j \in X} \Delta Y_{j t}$ capture, respectively, variation in output arising from new firms and exit of old ones. Their net effect represents plant extensive margin EXl. Surviving firms $(B)$ are divided in four groups indexed by $i=\{S, G$, $A, D\}$. Terms $\sum_{i \in S} \Delta Y_{i j t}$ and $\sum_{i \in G} \Delta Y_{i j t}$ capture, respectively, old items produced by established firms whose output has either declined $(i=S)$ or increased $(i=G)$. Their net effect corresponds to the intensive margin. The last two terms inside brackets, $\sum_{i \in A} \Delta Y_{i j t}$ and $\sum_{i \in D} \Delta Y_{i j t}$, capture, respectively, variation in output due to adding and dropping of items by continuing firms. Their net effect corresponds to the product extensive margin EX2.

Decomposition of output variation according to Equation 4 is presented in Table 6. The last row shows the percentage variation from 2005 to 2009. Previous rows show variation in year $t$ against $t$ - 1 , starting from $t=2006 .{ }^{14}$ The second column informs the total output growth. The remaining columns show output growth of each group according to the decomposition proposed by Equation 4.

The last row reveals that output increased by 27.54\% from 2005 to 2009 . The plant extensive margin 1 (EXl) was responsible for $2.45 \%$, while surviving firms throughout these years (group B) contributed with 25.09\%: $20.99 \%$ originated in the intensive margin, and $4.10 \%$ in extensive margin 2 (EX2).${ }^{15}$ In sub periods, EXl only delivered results better than those of EX2 in 2007, when growth from EXl was 11.47\%, against 1.22\% from EX2.

Overall, our results are in line with those reported for most countries: intensive margin contributing far more to output growth, followed by product margin and, lastly, by firm's margin. ${ }^{16}$ This superiority of the intensive margin should not really surprise. Once the production of a specific item is already in place, it is easier for a firm to respond to stimulus in either direction. It could, for instance, more easily expand production by using more hours as a response to higher demand. Logistics to supply

\footnotetext{
${ }^{14}$ Since we are interested in real variation, nominal values of each product were deflated by the appropriate four digit deflator of CNAE in accordance to the Brazilian National Account System. Given the nature of the decompositions presented in Table 7, deflating was not necessary.

15 These results are almost identical to those reported by BRS(2010) for the USA from 1992 to 1997.

${ }^{16}$ An exception was the study of Navarro (2012) for Chile, who reported the product margin coming first and the intensive margin second in determining real growth in manufacturing sales from 1996 to 2003.
} 
this extra amount would be an easier task to solve compared to an entrant's situation. Better network through the entire chain also facilitates adjustments through the intensive margin.

Table 6 - Decomposition of output growth (\%): 2005 to 2009

\begin{tabular}{|c|c|c|c|c|c|c|c|c|c|c|}
\hline \multirow[t]{2}{*}{ Period } & \multirow[t]{2}{*}{ Total } & \multicolumn{3}{|c|}{$\begin{array}{l}\text { Plant Entry and } \\
\text { Exit (EX1) }\end{array}$} & \multicolumn{3}{|c|}{$\begin{array}{l}\text { Intensive Margin: produce more } \\
\text { or less of existing items }\end{array}$} & \multicolumn{3}{|c|}{$\begin{array}{l}\text { Product Add and } \\
\text { Drop (EX2) }\end{array}$} \\
\hline & & Net & Entry & Exit & Net & More & Less & Net & Add & Drop \\
\hline $2005-2006$ & 6.64 & -0.71 & 4.29 & -5.00 & 7.04 & 17.33 & -10.29 & 0.32 & 6.06 & -5.74 \\
\hline 2006-2007 & 25.15 & 11.47 & 13.64 & -2.17 & 12.46 & 19.59 & -7.12 & 1.22 & 6.35 & -5.13 \\
\hline $2007-2008$ & 17.89 & 0.52 & 2.22 & -1.70 & 16.63 & 22.27 & -5.64 & 0.74 & 5.02 & -4.28 \\
\hline $2008-2009$ & -15.88 & -0.52 & 3.83 & -4.35 & -15.31 & 9.43 & -24.75 & -0.05 & 4.89 & -4.94 \\
\hline 2005-2009 & 27.54 & 2.45 & 11.73 & -9.28 & 20.99 & 29.51 & -8.52 & 4.10 & 13.25 & -9.15 \\
\hline
\end{tabular}

Notes. Table reports output growth decomposition in extensive margin due to entry and exit of firms (EX1), due to intensive margin and due to extensive margin of surviving plants that add and retire products (EX2).

Similar arguments may justify the product extensive margin (EX2) as second in determining total output variation. Compared to the firm's extensive margin (EXl), implementing adjustment in the production mix seems an easier task once a firm's internal structure (lawyers, accountants, managers etc.) is already set up. As an example, a continuing firm could benefit from existing networks and logistics, which would have to be built from scratch in the case of an entrant. Response to external stimulus should then happen more rapidly and less costly for incumbents (either by adjusting production or changing the mix).

The importance of the product margin can be better assessed if its contribution to growth is considered in relative terms. The net growth of the intensive margin represented $76.2 \%$ of the aggregate increase from 2005 to 2009 (20.99\% out of $27.54 \%$ ). The product margin contributed with $14.9 \%$ for the aggregate growth (4.90\% in $27.54 \%)$, which is a considerable amount since we are not simply talking about adjusting the volume of an already produced item.

Looking only at the positive part of each margin among continuing firms reveals more importance to the addition of new varieties. From 2005 to 2009, the incumbent's positive part expanded by $42.76 \%$, of which $29.51 \%$ was due to increasing the output of old items, and $13.25 \%$ from 
new items. ${ }^{17}$ These numbers imply that $31 \%$ of total (gross) increase in output of established firms was due to the production of new varieties. What makes the net contribution of the product margin smaller is the similar high proportion of retirement of items, which, on the other hand, opens space for the introduction of new varieties, especially if a firm is not willing to incur in profound and (sometimes) costly investments in order to have a new product in the production mix.

The fact that the firm's margin contributes least to output growth should not surprise, since it is in line with the findings reached by similar research on other countries. The real surprise is the lack of attention the product margin, which comes second in relevance, has received from the profession.

\subsection{Production Growth Decomposition and the Business Cycle}

The behavior of each margin over business cycles is another theme not explored by the profession. Little (if nothing) is known about this relation. In order to advance in this area, we bring some preliminary stylized facts based on the correlation between the annual growth rate of the Brazilian GDP and two of its components (manufacturing and investment) against the growth rate of each source of output growth in manufacturing, according to the decomposition presented in Table 6. It is worth emphasizing that this exercise does not intend to bring definite stylized facts, since correlations are computed based solely on 4 data points (from 2006 to 2009). Despite this limitation, the exercise is a good starting point to think how each margin behaves over cycles.

Correlations are presented in Table $7 .{ }^{18}$ The first thing to observe (in column 2) is the almost perfect positive correlation between the total net effect $\left(\Delta Y_{t}\right)$ and all three GDP variables, the highest being with the manufacturing GDP (0.996). ${ }^{19}$ Since most of the total net effect was due to changes in the intensive margin, it is not surprising it had an almost perfect correlation with NIPA measures.

${ }^{17}$ As a comparison, the output from new firms generated growth of $11.73 \%$ (see Table 6).

${ }^{18}$ Figures Al, A2, and A3 in the appendix allow visualizing the evolution of some NIPA growth measures (in the right scale of each plot) against the growth rate of each margin (in the left scale of each plot).

19 That this correlation is almost 1 is also a relief, as it indicates a well conducted treatment given to the microdata, including the deflation of each good separately. 
In accordance to the view that it is easier for an established firm to follow short run cycles (through intensive and/or extensive margins), correlations of the net EX2, which are all above 0.89, are much higher than those of the net firm margin (EX1), which range from 0.526 to 0.647 . The portion of each margin responsible for generating positive effect in the output keeps a similar pattern, with the intensive margin presenting very high correlations with GDP measures (all above 0.92), followed by the addition of products by continuing firms (column EX2 add, in Table 7). Correlations against the positive effect caused by firm entry (column EX1 entry) were the smallest.

Looking at the negative effects, we again observe very high correlations (minimum of 0.962 ) between the intensive margin and the GDP aggregates (column INT less). This indicates that when GDP grows stronger, the negative effect becomes milder (less negative). The high correlation seems in accordance to the view that it is easier for a continuing firm to make adjustments mainly by dimensioning the output of already produced items. The output variation arising from dropping items from the production mix (column EX2 drop) has an almost zero correlation against GDP and manufacturing GDP, being only a little higher (at 0.237 ) when confronted to the investment. These low correlations may indicate that the decision to drop products is a more strategic move, and, as such, should not be extremely impacted by short run cycles. On the other hand, the negative effect arising from firms' margin (EX1 exit) should be expected to correlate positively with cycles, since bad economic moments imply higher firm mortality. The numbers confirm this view since the estimated correlations ranged from 0.643 to 0.743 .

Table 7 - Correlation between annual growth rate of GDP and its components against growth rate in different product decomposition. Period: 2006-2009

\begin{tabular}{c|cccc|ccc|ccc}
\hline \multirow{2}{*}{ Variables } & \multicolumn{4}{|c|}{ Net Effect } & \multicolumn{3}{c|}{ Positive Effects } & \multicolumn{3}{c}{ Negative Effects } \\
& Total & $\begin{array}{c}\text { EX1 } \\
\text { net }\end{array}$ & $\begin{array}{c}\text { INT } \\
\text { net }\end{array}$ & $\begin{array}{c}\text { EX2 } \\
\text { net }\end{array}$ & $\begin{array}{c}\text { EX1 } \\
\text { entry }\end{array}$ & $\begin{array}{c}\text { INT } \\
\text { more }\end{array}$ & $\begin{array}{c}\text { EX2 } \\
\text { add }\end{array}$ & EX1 exit & INT less & $\begin{array}{r}\text { EX2 } \\
\text { drop }\end{array}$ \\
\hline GDP & 0.993 & 0.608 & 0.964 & 0.915 & 0.490 & 0.940 & 0.636 & 0.643 & 0.974 & 0.056 \\
GDP manuf. & 0.996 & 0.647 & 0.952 & 0.934 & 0.528 & 0.928 & 0.644 & 0.661 & 0.962 & 0.064 \\
GDP invest. & 0.983 & 0.526 & 0.985 & 0.894 & 0.366 & 0.981 & 0.472 & 0.743 & 0.983 & 0.237 \\
\hline
\end{tabular}

The Net Effect columns refer to the net results of each margin and the aggregate net result, which is under column Total. The columns under Positive Effects (Negative Effects) present only the part of each margin that contributes to the increase (decrease) of the output of that specific margin. 


\section{Surviving Firms}

This last section focuses only on surviving firms. The reason for this cutoff lies on the fact that they are responsible for the product extensive margin (EX2), which we want to study more carefully.

We initially take a picture and verify the proportion of firms according to actions towards scope, conditioning on some characteristics (panel A of Table 8). The distribution according to the output generated by surviving firms (panel B of Table 8) is also verified. Following BRS (2010), there are four mutually exclusive possibilities regarding changes in the productive mix: (i) "no change", when a firm does not add nor retire any variety; (ii) "drop", when at least one product is taken out of the production mix; (iii) "add", when at least one new item is incorporated to the production mix; and (iv) "both", for adding and dropping at least one product.

Panel A of Table 8 shows the percentage of firms enrolled in each action. In the second column ("Total") we see that only $37.3 \%$ have not changed the productive mix. The remaining $62.7 \%$ was distributed as follows: $9.2 \%$ added at least one product, $8.9 \%$ dropped at least one product, and $44.6 \%$ added and dropped at least one variety.

Among multiproduct firms (MP), only $13.2 \%$ did not promote any change, $17.1 \%$ have added, $16.5 \%$ only dropped, and $53.1 \%$ added and dropped products. Similar distribution is observed among MI and MS, with the largest share of firms engaging in both actions $(59.9 \%$ and $62.7 \%$, respectively) and the smallest fraction not conducting any change $(9.3 \%$ and $7.9 \%$, respectively). 
Table 8 - Share of firms and output, among surviving firms, according to action towards scope and characteristics: MP, MI, MS, exporting status, and size. Period: 2005-2009

\begin{tabular}{ccccccccc}
\hline Action regarding scope & Total & MP & MI & MS & $\begin{array}{c}\text { Exporters } \\
\text { (X) }\end{array}$ & $\begin{array}{c}\text { Non } \\
\text { exporters } \\
\text { (NX) }\end{array}$ & $\begin{array}{c}10 \% \\
\text { larger* }\end{array}$ \\
\hline \multicolumn{7}{c}{ Panel A: Share of firms } \\
\hline None & 37.3 & 13.2 & 9.3 & 7.9 & 32.5 & 39.7 & 28.7 \\
Add product(s) only & 9.2 & 17.1 & 16.1 & 15.2 & 11.8 & 7.9 & 14.4 \\
Drop product(s) only & 8.9 & 16.5 & 14.8 & 14.1 & 11.4 & 7.6 & 12.9 \\
Both:added and dropped & 44.6 & 53.1 & 59.9 & 62.7 & 44.4 & 44.8 & 44.1 \\
\hline \multicolumn{7}{c}{ Panel B: Share of output (of the specific group of each column) } & \\
\hline None & 26.6 & 14.9 & 9.8 & 7.7 & 24.4 & 37.8 & 18.8 \\
Add product(s) only & 13.9 & 16.7 & 16.4 & 12.9 & 14.5 & 11.2 & 13.6 \\
Drop product(s) only & 12.1 & 14.5 & 12.9 & 15.7 & 12.0 & 12.4 & 11.1 \\
Both: added and dropped & 47.4 & 53.9 & 60.9 & 63.6 & 49.1 & 38.7 & 56.4 \\
\hline
\end{tabular}

Notes. *With respect to output value. Columns add to $100 \%$.

Regarding participation in external market, non-exporters were more likely to leave their mix unchanged: $39.7 \%$ compared to $32.5 \%$ among exporters. In the opposite direction, the fraction of those that have only added or only dropped product(s) was higher among exporters: respectively, $11.8 \%$ and $11.4 \%$ against $7.9 \%$ and $7.6 \%$ for NX. There was basically no difference between the proportion of firms conducting both actions: $44.4 \%$ for X and $44.8 \%$ for NX. Firms belonging to the top decile (with respect to output value) were less likely to keep steady their production mix $(28.7 \%)$ when compared to all firms together (37.3\%). Larger companies were more likely to add new products (14.4\% against $9.2 \%)$ and retire old ones (12.9\% against $8.9 \%)$. No substantial difference was found in the proportion of firms conducting both actions.

Panel B informs the contribution of each action group for the aggregate output among surviving firms from 2005 to $2009 .^{20}$ Those $37.3 \%$ that did not change scope were responsible for only $26.6 \%$ of the output. The remaining $62.7 \%$ that modified the mix were responsible for $73.4 \%$ of the output which was distributed as follows: $13.9 \%$ generated by firms that only added products, $12.1 \%$ by droppers, and $47.4 \%$ by firms doing both.

${ }^{20}$ One should be cautious for not directly comparing the results of the product decomposition presented in Table 8 with the one in Table 6 . In the last, the analysis concerns the contribution to growth, while the former is interested in the contribution to total amount produced. 
It is clear that an average firm that promotes changes in the production mix contributes far more to aggregate output than a standard one that does not. But this conclusion, well pictured by comparing the "Total" column of panels A and B (Table 8), does not seem to be caused by firms being MP, MI, or MS. Export status and firm size are where big differences in panels A and B reside. Starting with size, while $28.7 \%$ of the firms belonging to top decile did not pursue any change in scope, their contribution to output was much smaller, at $18.8 \%$. And while $44.1 \%$ of these larger firms added and dropped items from their productive mix, their contribution to output was much larger (56.4\%). Similar inversion happened among exporters: $32.5 \%$ of them did not alter their mix, but these firms only contributed to $24.4 \%$ of the output in the group. The remaining $67.5 \%$ that altered the mix contributed with $75.6 \%$ of the output among exporters.

Although nothing can be directly said regarding productivity, our results suggest that most productive firms are more likely to change scope, since the inversion just mentioned happened among exporters and larger firms, groups where higher productivity is expected. This would be in line with BRS (2010) for whom such characteristics also indicate that a firm is more likely to afford paying for product specific sunk costs. ${ }^{21}$

Overall, our results are in line with those reported for other countries: the intensive margin contributes far more to output growth, followed by product margin and, lastly, by firm's margin. The percentage of contribution of each varies depending on the period analyzed. The profession has not even attempted to explain, neither empirically nor theoretically, what is behind the differences in these proportions across countries or even inside a country but over the business cycle.

\section{Output and Output Growth}

Although $62.7 \%$ (Table 8) of all surviving firms have conducted some type of modification in their scope (by adding, retiring, or doing both), Table 6 shows that the main source of output growth from 2005 to 2009 was the

${ }^{21}$ BRS (2010) based their explanations using similar arguments encountered in models of firm entry and exit of Hopenhayn (1992), Melitz (2003) and Bernard, Redding and Scott (2006), with the exception that now each firm would require paying product specific sunk costs. 
intensive margin (20.99\%), followed by scope (4.10\%). These results are not contradicting each other, since results in Table 8 refer to output produced from 2005 to 2009, while Table 6 informs about output variation.

The high share of firms promoting modification in scope between 2005 and 2009 does not conflict with the fact that, for most of them, response to business cycles happens mostly by adjusting already produced items, which seems reasonable and expectable for at least two reasons. Firstly, it is easier and less costly to react to cycles by increasing or decreasing the amount produced of old items than by adding or retiring products. Secondly, it makes sense that a serious response to short run aggregate swings would require adjustment in the production of goods that are most important to a firm's output. And indeed, as shown in Table 2, most of the contribution to a firm's output tends to come from one single product, which would make it a strong candidate to suffer adjustments over business cycles.

\subsection{Output Growth Performance and Scope Strategy}

Results in panel B of Table 8 show association between actions in the productive mix and output level. We are now interested in verifying whether there is any relation between output growth and scope strategy.

Product decomposition as proposed by Navarro (2012), which is similar to the one carried out in subsection 5.2, was first performed, but now the groups are divided according to their actions towards scope. Considering $\sum_{j \in B} \Delta Y_{j t}$ as the output variation of a surviving firm $j$, between year $t$ and $t-1,22$ which necessarily must have adopted only one of the following actions indexed by $h=\{U, M, L, E\}$ : kept the same productive mix, $U$; altered the mix and ended with more items, $M$; less items, $L$; or with the same amount of varieties, E. Expression 6 formalizes this decomposition, while Table 9 summarizes the results.

$$
\sum_{j \in B} \Delta Y_{j t}=\sum_{h \in U} \Delta Y_{h t}+\sum_{h \in M} \Delta Y_{h t}+\sum_{h \in L} \Delta Y_{h t}+\sum_{h \in E} \Delta Y_{h t}
$$

\footnotetext{
${ }^{22}$ Surviving firms, labeled here as group $j$, are the same as group $B$ previously shown in the decomposition according to Equations 3 and 4.
} 
Aggregate output variation among continuing firms is presented in the $2^{\text {nd }}$ column. The $3^{\text {rd }}$ and $4^{\text {th }}$ columns present, respectively, results for group $U$ and for the joined variation reached by the group of firms that pursued any change in the productive mix $(M+L+E)$. The last three columns present individual results for $M, L$, and $E$, respectively. Each row informs the specific period according to the $1^{\text {st }}$ column.

On average, output growth was similar in firms that did and did not change the scope. Among the first group, the largest increase was noticed among those that increased the number of varieties (M). Group L contributed with approximately $11 \%$ of the aggregate growth among surviving firms in 2007 and 2008, despite representing firms that produced less items. They however performed poorly in years of smaller aggregate output growth (2006 and 2009). Particularly during the financial crisis (2009), the drop in output of group $L$ was $4.61 \%$, which represented $30 \%$ of total contraction among surviving firms.

Table 9 - Output growth rate (\%) of surviving firms and change in product mix. 2005 2009

\begin{tabular}{|c|c|c|c|c|c|c|}
\hline \multirow[b]{2}{*}{ Period } & \multirow[b]{2}{*}{$\begin{array}{l}\text { Total } \\
\text { Surviving } \\
\text { (B) }\end{array}$} & \multirow[b]{2}{*}{$\begin{array}{l}\text { No change in } \\
\text { product mix } \\
\text { (U) }\end{array}$} & \multicolumn{4}{|c|}{ Changed product mix } \\
\hline & & & $\begin{array}{c}\text { Total } \\
(M+L+E)\end{array}$ & $\begin{array}{l}\text { More varieties } \\
\text { (M) }\end{array}$ & $\begin{array}{l}\text { Less varieties } \\
\text { (L) }\end{array}$ & $\begin{array}{c}\text { Same amount of } \\
\text { varieties }(E)\end{array}$ \\
\hline $2005 / 2006$ & 7.35 & 4.42 & 2.94 & 2.99 & -0.55 & 0.49 \\
\hline $2006 / 2007$ & 13.68 & 6.55 & 7.13 & 3.73 & 1.61 & 1.79 \\
\hline $2007 / 2008$ & 17.37 & 8.34 & 9.03 & 6.11 & 1.92 & 1.01 \\
\hline $2008 / 2009$ & -15.36 & -7.26 & -8.1 & -1.91 & -4.61 & -1.58 \\
\hline
\end{tabular}

Source: PIA Product - IBGE, 2005 a 2009.

As an overall comparison, Navarro found that, from 1996 to 2003, 85\% of the increase in the manufacturing output among Chilean surviving firms happened among those that promoted some type of change in scope. Firms that produced less items contributed with $22.7 \%$ of the aggregate result. Confronting results of Chile and Brazil serves more for illustrative purpose than for establishing empirical regularities. The reason resides on the fact that during the periods analyzed (1990s and early 2000s for Chile and 2005 to 2009 for Brazil) these economies, specially the Chilean, were facing profound transformations that could even be characterized 
as changes in their steady states. The results, however, may help future analysis to enhance our understanding of the relation between product mix change and output growth over business cycle and through transition equilibrium paths.

Table 10 - Correlation between annual growth rate of GDP and some of its components against growth rate of surviving firm's output according to action towards scope. Period: 2006-2009

\begin{tabular}{|c|c|c|c|c|c|c|}
\hline \multirow[b]{2}{*}{ Variable } & \multirow{2}{*}{$\begin{array}{l}\text { Total } \\
\text { surviving } \\
\text { (B) }\end{array}$} & \multirow{2}{*}{$\begin{array}{l}\text { No change in } \\
\text { product mix } \\
\text { (U) }\end{array}$} & \multicolumn{4}{|c|}{ Changed productive mix } \\
\hline & & & $\begin{array}{c}\text { Total } \\
(M+L+E)\end{array}$ & $\begin{array}{c}\text { More } \\
\text { varieties } \\
\text { (M) }\end{array}$ & $\begin{array}{c}\text { Less } \\
\text { varieties } \\
\text { (L) }\end{array}$ & $\begin{array}{l}\text { Same amount } \\
\text { of varieties }(E)\end{array}$ \\
\hline GDP growth (\%) & 0.969 & 0.965 & 0.969 & 0.905 & 0.979 & 0.997 \\
\hline GDP manuf growth (\%) & 0.958 & 0.952 & 0.960 & 0.888 & 0.974 & 0.999 \\
\hline GDP invest growth (\%) & 0.989 & 0.979 & 0.994 & 0.958 & 1.000 & 0.967 \\
\hline
\end{tabular}

Source: Authors' computation

Finally, Table 10 reports correlations between growth rates in some NIPA measures (GDP, manufacturing GDP, and investment) and output of surviving firms according to their action towards scope. ${ }^{23}$ All correlations are positive and very high, close to 1 . Given that we only had 4 years of annual data, it is not appropriate to take definitive conclusions regarding differences among them. Despite this restriction, it is impossible to avoid noting that output increase from firms that ended up with more varieties (group M) had the smallest correlation against GDP and manufacturing GDP growth $(0.905$ and 0.888 , respectively), which contrasts with higher correlations for those firms that ended with less varieties (0.979 and 0.974). As more data become available, it should be interesting to carry out formal tests to verify if these differences persist and whether they are significant. It would be similarly interesting to compute similar correlations for other countries in order to verify whether this is a general pattern of any economy. Regarding other correlations, it also deserves attention the almost identical results among firms that did (group U) and did not (group B) promote any change in scope $\left(3^{\text {rd }}\right.$ and $2^{\text {nd }}$ columns, respectively).

${ }^{23}$ These refer to the annual growth rates reported in Table 9. 


\subsection{Concomitant Change in Product Switching and Firm Characteristic}

The concomitant relation between changes in firm's characteristics and product switching was also verified by estimating (by OLS) the following equation suggested by BRS (2010):

$$
\Delta Z_{j i, t / t-4}=\alpha_{i t-4}+\beta_{1} N A d d_{j i, t / t-4}+\beta_{2} \operatorname{NDrop}_{j i, t / t-4}+\varepsilon_{j t}
$$

$\Delta Z_{j i, t / t-4}$ is the log difference in characteristic $Z$ of firm $j$ belonging to sector $i$, between years $t$ and $t-4$. We consider the following characteristics: output, number of employees and TFP. $N A d d_{j i, t / t-4}$ is a dummy variable that equals 1 when more items were produced in 2009 compared to 2005 (group $\mathrm{M}$ in the decomposition according to Equation 5). NDrop $p_{j, t / t-4}$ is another dummy variable that equals 1 when the amount of varieties produced in 2009 was smaller than in 2005 (group L in the decomposition according to Equation 5). $N A d d_{j i, t / t-4}=N D r o p_{j i, t / t-4}=0$ for firms producing the same amount of varieties in 2009 and 2005, regardless of their being of the same type (groups $U$ and $E$ in Equation 5). $a_{i t-4}$ captures sector fixed effects according to the sector belonged to in 2005. Results are in Table 11.

Table 11 - Product Switching and Concomitant Changes in Firm Characteristics, 20052009

\begin{tabular}{|c|c|c|c|c|}
\hline Variable (characteristic) & Net Add & Net Drop & Observations & $\mathrm{R}^{2}$ \\
\hline \multirow[t]{2}{*}{$D$ In(output) } & $0.1068^{* * *}$ & $-0.1382^{\star \star *}$ & 18,338 & 0.05 \\
\hline & $(0.0174)$ & $(0.0177)$ & & \\
\hline \multirow[t]{2}{*}{ D In(n.employees) } & $0.1521^{* * *}$ & $-0.0983^{* * *}$ & 18,338 & 0.05 \\
\hline & $(0.0320)$ & $(0.0325)$ & & \\
\hline \multirow[t]{2}{*}{$\mathrm{D} \ln (\mathrm{TFP})$} & $0.1466^{\star *}$ & $-0.1266^{* *}$ & 18,338 & 0.05 \\
\hline & $(0.0627)$ & $(0.0638)$ & & \\
\hline
\end{tabular}

Note. Standard errors in parenthesis. Significance: ${ }^{* * *} 1 \%{ }^{* *} 5 \%$ e ${ }^{*} 10 \%$. Authors' computation.

Firms that have net added items increased their output, on average, by $10.68 \%$ more than firms that kept the same amount of items produced $(\mathrm{U}+\mathrm{E})$. They also added $15.21 \%$ more employees and expanded TFP by $14.66 \%$ over the control group. In the opposite direction, firms that 
have net dropped items saw their output increasing, on average, 13.82\% less than the base group. Variation in number of employees and TFP were, respectively, $9.83 \%$ and $12.66 \%$ smaller than groups $\mathrm{U}$ and $\mathrm{E}$ taken together. ${ }^{24}$

It is important to have in mind that these findings do not tell anything about causality, given the contemporaneity between action towards scope and variation in characteristics.

\subsection{Level Characteristic and Product Switching Decision}

We also verify possible structural relations between firm's characteristics and product switching strategy. Our analysis distinguishes from those carried by BRS (2010) and Navarro (2012) in the sense that their econometric procedure to estimate probabilities of dropping a product was totally divorced from the analysis of adding an item. Even the covariates used to evaluate different actions were not all the same, which may raise questions concerning the robustness of their conclusions. We think that this separate analysis may hide important aspects that would fit in a more general story.

All possibilities were assessed using a multinomial probit to estimate the probability that a surviving firm $j$ in sector $i$ would adopt one of the following exhaustible and mutually exclusive strategies in year $t$ :

$$
\text { strategy }_{j, t}= \begin{cases}0 & \text { if } j \text { does not alter the scope } \\ 1 & \text { if } j \text { only adds new varieties } \\ 2 & \text { if } j \text { only drops varieties } \\ 3 & \text { if } j \text { adds and drops varieties }\end{cases}
$$

Probabilities are evaluated based on past characteristics (at $t-h$ ) to avoid contemporaneity. The following covariates are used in the exercise: natural logarithm of the number of employees $(\mathrm{empl})$, natural logarithm of total

\footnotetext{
${ }^{24}$ An important observation made by BRS (2010): The correlations shown by these results capture equilibrium relationships between endogenous variables since the choice of product mix is influenced by firms' characteristics. Thus, the coefficients capture nonrandom decisions affecting changes in the number of products and the impact of these decisions on the characteristics considered .
} 
factor productivity $(t f p)$, and exporting status $(X)$, with $X=1$ indicating an exporter and $X=0$ otherwise. The following equation was estimated:

$$
\operatorname{Pr}\left(\text { strategy }_{j i, t}\right)=\beta_{0}+\beta_{1} \text { empl }_{j i, t-h}+\beta_{2} t f p_{j i, t-h}+\beta_{3} X_{j i, t-h}+\varepsilon_{j i, t}
$$

The results, presented in Table 12, are for strategies in years $t=2006$ to $t=2009$ and characteristics in $t$-1. Probabilities should be compared to the base strategy $=0$, which is "does not alter the scope".

Regarding the TFP, results indicate that being more productive in the previous year reduces the probability of adding and dropping an item, which seems a surprising result. BRS(2010) and Navarro (2012) observed that higher TFP at time $t$ increases the probability of a firm adding a product also at time $t$, but none of them analyzed the relation with dropping. ${ }^{25}$

A possible explanation for our results is that more productive plants are also more satisfied with their overall performance, feeling less need to periodically change the mix. It could also be that excessive variation in the productive mix may actually damage productivity by avoiding firms to improve process of items already produced. Notice that our result does not contradict theoretical predictions suggesting that more productive plants should produce more items, which is a level association while we are analyzing variation in the number of items over a short time horizon.

Our results also indicate that being an exporter in the past increases the probability of adding and dropping products. This suggests that exposition to external market may lead firms to react to competition by switching products. They would retire products that are less competitive and would add new items believed to have higher chance of succeeding. The contact with foreign markets may help them to learn about new products and trends, stimulating changes in their mix and improving resource allocation inside firms through the product extensive margin, which may have important aggregate results for the economy. It remains to be studied if the import of a specific item impacts similarly through this same channel. ${ }^{25}$ Navarro (2012) encountered a negative relation between variation in TFP and dropping items, but
has not analyzed the relation with respect to TFP level. 
Table 12 - Multinomial probit estimates of the following equation:

\begin{tabular}{|c|c|c|c|c|c|}
\hline Strategy & covariate & $T=2006$ & $t=2007$ & $t=2008$ & $t=2009$ \\
\hline \multirow{3}{*}{ strategy 1} & \multirow[t]{2}{*}{ empl } & $0.0094^{\star \star \star}$ & $0.0073^{\star \star \star}$ & $0.0093^{\star \star \star}$ & $0.0086^{\star * *}$ \\
\hline & & $(0.0017)$ & $(0.0016)$ & $(0.0015)$ & $(0.0013)$ \\
\hline & \multirow[t]{2}{*}{$t f p$} & $-0.003^{\star * *}$ & $-0.0023^{\star *}$ & $-0.0026^{\star \star *}$ & $-0.0024^{* \star \star}$ \\
\hline \multirow[t]{3}{*}{ only add } & & $(0.001)$ & $(0.0009)$ & $(0.001)$ & $(0.0008)$ \\
\hline & \multirow[t]{2}{*}{$X$} & $0.0136^{* * *}$ & $0.0141^{* * *}$ & $0.0136^{\star * *}$ & $0.0188^{* * *}$ \\
\hline & & $(0.0042)$ & $(0.004)$ & $(0.0038)$ & $(0.0036)$ \\
\hline \multirow{6}{*}{ strategy 2} & \multirow[t]{2}{*}{ empl } & $0.0104^{\star * *}$ & $0.0104^{\star * *}$ & $0.0118^{\star \star \star}$ & $0.0081^{* * *}$ \\
\hline & & $(0.0016)$ & $(0.0016)$ & $(0.0015)$ & $(0.0014)$ \\
\hline & \multirow[t]{2}{*}{$t f p$} & $-0.0028^{\star \star \star}$ & $-0.0021^{\star *}$ & $-0.0037^{\star \star \star}$ & $-0.0016^{*}$ \\
\hline & & $(0.001)$ & $(0.001)$ & $(0.0009)$ & $(0.0009)$ \\
\hline & \multirow[t]{2}{*}{$x$} & $0.0172^{\star * \star}$ & $0.0177^{\star \star *}$ & $0.0149^{\star \star \star}$ & $0.0167^{\star \star \star}$ \\
\hline & & $(0.004)$ & $(0.004)$ & $(0.004)$ & $(0.0039)$ \\
\hline \multirow{6}{*}{$\begin{array}{l}\text { strategy } 3 \\
\text { add and } \\
\text { drop }\end{array}$} & \multirow[t]{2}{*}{ empl } & $-0.0134^{* \star *}$ & 0.0018 & $-0.006^{\star *}$ & $-0.0105^{\star \star \star}$ \\
\hline & & $(0.0028)$ & $(0.0028)$ & $(0.0026)$ & $(0.0023)$ \\
\hline & \multirow[t]{2}{*}{$t f p$} & $0.0028^{*}$ & $-0.0035^{\star *}$ & 0.0004 & 0.002 \\
\hline & & $(0.0016)$ & $(0.0016)$ & $(0.0015)$ & $(0.0014)$ \\
\hline & \multirow[t]{2}{*}{$x$} & $-0.0155^{\star *}$ & $0.0149^{* *}$ & $-0.0192^{* \star *}$ & $-0.0144^{* *}$ \\
\hline & & $(0.0069)$ & $(0.0069)$ & $(0.0067)$ & $(0.0067)$ \\
\hline \multicolumn{2}{|c|}{ Prob $>$ Wald } & 0.0000 & 0.0000 & 0.0000 & 0.0000 \\
\hline \multicolumn{2}{|c|}{ № OBS. } & 22545 & 22989 & 23549 & 24343 \\
\hline
\end{tabular}

Note. Standard errors in parenthesis. Significance: ${ }^{* *} 1 \%$. ${ }^{* *} 5 \% \mathrm{e}^{*} 10 \%$. Authors' computation.

Estimates also indicate that having more employees (representing size) in $t$ - 1 results in higher probability of either increasing $(0.73 \%$ to $0.94 \%)$ or decreasing $(0.81 \%$ to $1.18 \%)$ the number of items produced. BRS (2010) and Navarro (2012) also reached similar conclusions when evaluating separately the probability of dropping and adding a product. BRS initially considered unexpected that larger firms would also be more likely to drop varieties. The surprise arose because they firstly drew conclusions based on the firm's exit literature, according to which a larger firm would be less likely to die. However, in the case of product switching, they later observed that the ability to drop items may be behind longevity. 
The broader view brought by the multinomial probit provides a more complete story regarding our results. The fact that larger firms and exporters are more likely to add and drop varieties suggests they are more likely to afford paying for product sunk costs. They may as well have better managerial ability, which allows them to alter their mix at smaller cost, which is in line with the explanations provided by Nocke e Yeaple (2006) for why some firms produce more varieties than others.

Results for strategy 3 (adding and dropping products) are less robust and harder to interpret. For instance, the TFP was significantly positive to explain action 3 in 2006, but negative in 2007. For 2008 and 2009, it was not significant. Number of employees was not significant in 2007, but it was significantly negative in other years. And exporting status also had different signals over the years. We are less confident in even trying to explain these results, so we do not pursue this task.

Important, estimates about strategies 1 and 2 were almost unaffected throughout the years, including 2009, during the financial crisis. Our conclusions were unaltered even when characteristics were lagged for two years $(t-2)$, as shown in Table A3 in the appendix.

\section{Conclusions}

To our knowledge, this is the first work that characterizes the Brazilian manufacturing sector according to its production scope, which was possible after combining two surveys at the firm level. We bring several stylized facts along the lines of the literature on firm heterogeneity.

Compared to single product firms, multiproduct counterparts are larger, have higher output, greater labor productivity, higher TFP, and are more likely to be exporters. In another analysis, we verified that, from 2005 to 2009 , only $37.3 \%$ of the firms did not modify the productive mix. When considering multiproduct plants, this percentage falls to $13.2 \%$, showing a very high propensity for firms to alter the items produced. 
By decomposing the output in several distinguished manners, it was verified that the product extensive margin had higher contribution to output growth than the conventional extensive margin arising from the entry and exit of firms. We also verified that more than $50 \%$ of variation in output among surviving firms was originated in firms that promoted modifications in their productive scope, showing the relevance of such strategy.

According to Bernard and Okubo (2013), little is known about scope adjustment over business cycle. In order to enhance our knowledge in this direction, we verified that the growth rate in the intensive margin had the largest correlation, all very close to 1 , with three NIPA growth variables: GDP, manufacturing GDP, and investment. Product extensive margin came in second, with correlations varying from 0.89 to 0.93 , while the firms's margin came in the last position, with correlations ranging from 0.52 to 0.65 .

To further enhance our understanding about scope and business cycle, we studied the determinants of changes in the production mix of surviving firms from 2005 to 2009. Larger firms (by number of employees) were found to have higher probability of either adding or dropping products from their production mix. A more sophisticated management among larger firms, which may facilitate such changes at smaller cost, may be the cause of this result.

Firms with higher TFP had less probability of either adding or dropping products over the cycle. We have raised the following hypothesis to explain this result: more productive firms are more likely to be satisfied with their performance and choices, which would discourage them from promoting constant changes. Instead, they would prefer to focus on efficiency gains in items they already manufacture.

Among surviving firms, we also verified that exporters are more likely to add and drop items from their production mix, which may be due to fierce international competition. Given the relevance of the product extensive margin, exposition to international market seems to work its way towards higher aggregate efficiency by forcing firms to choose a better mix. 


\section{Bibliography}

Alves, Juliana D., Ferreira, Mauro S. 2013. "Impacto do crescimento do comércio internacional na indústria brasileira: competição desigual ou reestruturação?" $35^{\circ}$ Encontro Brasileiro de Econometria, Foz do Iguaçu, Brazil, 2013. (https://editorialexpress.com/cgi-bin/conference/download.cgi?db_name=sbe35\&paper_id=106).

Arkolakis, Costas, Muendler, Marc. 2010. "The extensive margin of exporting products : a firm-level analysis". NBER Working Paper Series 16641: 1-50.

Bernard, Andrew, Eaton, Jonathan, Jensen, J. Bradford, Kortum, Samuel. 2003. "Plants and Productivity in International Trade". American Economic Review 93(4):1268-1290.

Bernard, Andrew B., Okubo, Toshihiro. 2013. "Multi-Product Plants and Product Switching in Japan”. Tokyo: RIETI, Research Inst. of Economy, Trade and Industry 1-25.

Bernard, Andrew B., Redding, Stephen J., Schott, Peter K. 2010. "Multiple-Product Firms and Product Switching”. American Economic Review 100(1): 70-97, mar.

Bernard, Andrew B., Redding, Stephen J., Schott, Peter K. 2011. "Multi-product firms and trade liberalization". Quarterly Journal of Economics 126(3): 1271-1318.

Eckel, Carsten; Neary, J. Peter. 2010. "Multi-Product Firms and Flexible Manufacturing in the Global Economy". The Review of Economic Studies 77(1): 188-217.

Esteves, Luiz A. 2015. "Economias de escala, economias de escopo e eficência produtiva na indústria brasileira de transformação". In De Negri, F. e Cavalcante, L.R.M.T. (orgs.) Produtividade no Brasil:desempenho e determinantes, IPEA 69-118.

Goldberg, Pinelopi, Khandelwal, Amiti, Pavcnik, Nina and Topalova, Petia. 2010. "Multiproduct Firms and Product Turnover in the Developing World: Evidence from India," The Review of Economics and Statistics, MIT Press, 92(4), 1042-1049, November.

Iacovone, Leonardo; Javorcik, Beata. 2010. "Multi-product exporters : product churning, uncertainty and export discoveries". The Economic Journal 120: 481-499, n. May.

INTITUTO BRASILEIRO DE GEOGRAFIA E ESTATÍSTICA, IBGE. 2007. CLASSIFICAÇÃO NACIONAL DE ATIVIDADES ECONÔMICAS - CNAE: versão 2.0. 2. ed. Rio de Janeiro: IBGE. Disponível em: <http:// www.ibge.gov.br/home/estatistica/economia/classificacoes/cnae2.0/cnae2.0.pdf>. acesso em: ago. 2012.

INTITUTO BRASILEIRO DE GEOGRAFIA E ESTATÍSTICA, IBGE. 2011. LISTA de Produtos da Indústria. PRODLIST-Indústria 2010. Rio de Janeiro: IBGE. Disponível em <http://www.ibge.gov.br/home/estatistica/ economia/prodlist_industria/2010/prodlist2010.pdf>. Acesso em: jan. 2012.

INTITUTO BRASILEIRO DE GEOGRAFIA E ESTATÍSTICA, IBGE. 2000-2012. PESQUISA INDUSTRIAL 1996-2010. Empresa. Rio de Janeiro: IBGE 1: 15-29. Acompanha 1 CD-ROM, a partir de 1997. Disponível em: < http://www.ibge.gov.br/home/estatistica/economia/industria/pia/empresas/2010/defaultempresa.shtm>. Acesso em: jun. 2011

INTITUTO BRASILEIRO DE GEOGRAFIA E ESTATÍSTICA, IBGE. 2002-2012. PESQUISA INDUSTRIAL 1998-2010. Produto. Rio de Janeiro: IBGE 2: 18-29. Acompanha 1 CD-ROM, a partir de 1998. Disponível em: < http://www.ibge.gov.br/home/estatistica/economia/industria/pia/produtos/produto2010/defaultproduto.shtm> Acesso em: jun. 2011.

Mayer, Thierry, Melitz, Marc J., Ottaviano, Gianmarco. 2014. "Market Size, Competition, and the Product Mix of Exporters". American Economic Review 104(2): 495-536, Feb.

Melitz, Marc J., Ottaviano, Gianmarco I. P. 2008. “Market Size, Trade, and Productivity”. Review of Economic Studies 75(1): 295-316, Jan.

Melitz, Marc. 2003. "The impact of trade on intra-industry reallocations and aggregate industry productivity". Econometrica 71: 1.675-1.725. 
Navarro, Lucas. 2012. "Plant Level Evidence on Product Mix Changes in Chilean Manufacturing”. Journal of International Trade \& Economic Development 21(2): 165-195.

Nocke, Volker, Yeaple, Stephen R. 2006. "Globalization and endogenous firm scope”. Cambridge: NBER Working Paper Series 12322, 42p.

Söderbom, Mans, Weng, Qian. 2012. "Multi-product firms, product mix changes and upgrading: Evidence from China's state-owned forest areas". China Economic Review 23(4): 801-818, Dec.

\section{Appendix}

\section{Estimating TFP}

TFP is estimated as the difference between the observed and predicted output from a Cobb-Douglas production function. However, OLS estimates suffer from simultaneity and selection bias. Simultaneity occurs because productivity relies on estimates of predicted output, which depends on input usage. But since input decision is part of a profit maximization problem, productivity shocks affect input, output, and, ultimately, TFP, all simultaneously. OLS estimates become biased when not controlling for this type of shock. Selection bias may occur because firms with higher capital stock are more likely to survive and remain in the sample in the presence of adverse productivity shocks. As a result, the regression coefficient associated with capital stock may be biased, also affecting the predicted output and TFP. We deal with these problems following the methodology proposed by Levinsohn e Petrin (2003), which is based on the seminal work of Olley and Pakes (1996). Estimation happens through a semi-parametric procedure.

Oley and Pakes dealt with simultaneity using investment as instrument for unobserved productivity shocks. Levinsohn and Petrin, however, proposed controlling for the correlation between inputs and unobserved productivity shocks using consumption of raw material, fuel, and electricity. They argued that these variables respond faster to productivity shocks, while investment takes longer to adjust. Another advantage is to avoid the immense amount of missing observations presented in the investment information, which was a pattern in their dataset and also in ours. We followed suit and used consumption of raw materials and components as instruments for unobserved productivity shocks. 
Schor $(2004,2006)$ also followed the work of Olley and Pakes to estimate PTF among Brazilian manufacturing firms. ${ }^{26}$ Regarding labor usage, she argued not to be proper to think of labor as a highly mobile factor in Brazil, given high costs for hiring and firing workers. Another point is that production adjustment can take place through labor intensive margin. We followed her and opted for using the average number of employees not directly involved in the production to represent qualified workers ('white collars'), and average number of employees participating directly in the production process to represent non-qualified workers ('blue collars'). Both are treated as free variables in the model. Finally, we do not correct for selection bias directly, since we use unbalanced panel which minimizes the bias. This argument was also raised by Schor (2004) and Levinsohn e Petrin (2003).

Going to the model, consider the following Cobb-Douglas production function:

$$
y_{i t}=\beta_{0}+\beta_{p} E M P p_{i t}+\beta_{n p} E M P n p_{i t}+\beta_{r} r a w m_{i t}+\beta_{k} k_{i t}+\mu_{i t} .
$$

$y_{i t}$ is the logarithm of output of firm $i$ in year $t$, or in terms of our data, the log of the production value. EMP $p_{i t}$ and EMPnp $p_{i t}$ are, respectively, logarithm of the mean number of employees directly involved in the production, and logarithm of the mean number of employees not directly involved in the production. rawm $_{i t}$ is the expense with raw materials, and $k_{i t}$ the logarithm of capital stock. ${ }^{27} m_{i t}$ is a firm specific residual formed by two components: $\omega_{i t}$, which is the productivity shock known by firm $i$ but not by the econometrician; and $\varepsilon_{i t}$, the productivity shock not observed by both.

$m_{i t}$ is firm's $i$ use of input in year $t$. Input demand $m($.$) depends on k_{i t}$ and $\omega_{i t}$, being monotonically increasing in $\omega_{i t}: m_{i t}=m\left(k_{i t}, \omega_{i t}\right)$. This function can be represented in terms of observed variables: $h_{i t}=h\left(k_{i t}, \operatorname{rawm}_{i t}\right)$. Monotonicity allows inverting to evaluate firm's $i$ observed productivity as a function of expenses with raw material, capital stock, and labor, resulting in

$$
y_{i t}=\beta_{p} E M P p_{i t}+\beta_{n p} E M P n p_{i t}+\varphi_{i t}\left(k_{i t}, r a w m_{i t}\right)+\varepsilon_{i t}
$$

26 Souza (2009) compares recent approaches to estimate production functions.

27 This variable was calculated similarly to Alves and Silva (2008). The exception, however, is that we did not input data for missing values. 
where, $\varphi_{i t}\left(k_{i t}, \operatorname{rawm}_{i t},\right)=\beta_{0}+\beta_{k} k_{i t}+h\left(k_{i t}, \operatorname{rawm}_{i t}\right)$.

In the first stage an unbiased OLS estimate of $\beta_{p}, \beta_{n p}$, and $\varphi_{i t}($.$) was$ obtained using a third degree polynomial approximation in $h_{i t}$ and $r a w m_{i t}$, which allows estimating $h_{i t}$. The second stage identifies $\beta_{r}$ e $\beta_{k}$ by first assuming that the firm's observed productivity follows a first degree Markov process: $\omega_{i t}=E\left[\omega_{i t} \mid \omega_{i t-1}\right]+\xi_{i t}$. Using fitted values for $\varphi_{i t}($.$) in this stage,$ fitted values for $y_{i t}$ were obtained after estimating the next equation by nonlinear least square: ${ }^{28}$

$$
y_{i t}=\beta_{p} E M P p_{i t}+\beta_{n p} E M P n p_{i t}+\beta_{k} k_{i t}+E\left[\omega_{i t} \mid \omega_{i t-1}\right] .
$$

This estimation, however, requires a measure for the last term, which can be assessed by first estimating $\varphi_{i t}($.$) using \varphi_{i t}=\hat{y}_{i t}-\hat{\beta}_{p} E M P p_{i t}-\hat{\beta}_{n p} E M P n p_{i t}$. Given $\hat{\varphi}_{i t}($.$) and \hat{\beta}_{k}$, we obtain: $\hat{\omega}_{i t}: \hat{\omega}_{i t}=\hat{\varphi}_{i t}-\beta_{k} k_{i t}$. Finally, the functional form for $E\left[\omega_{i t} \mid \omega_{i t-1}\right]$ can be approximated by the following third degree polynomial: $\hat{\omega}_{i t}=\gamma_{0}+\gamma_{1} \hat{\omega}_{i t-1}+\gamma_{2} \hat{\omega}_{i t-1}^{2}+\gamma_{3} \hat{\omega}_{i t-1}^{3}$.

28 We used the Stata code "levpet" written by Petrin et. al. (2004). 
Table A.1 - Code's correlation between System of National Account and CNAE. Version 1.0 , four digits.

\begin{tabular}{|c|c|c|}
\hline $\begin{array}{l}\text { Code } \\
\text { SNC }\end{array}$ & Description SNC & CNAE \\
\hline 4 & $\begin{array}{l}\text { Manufacture of non-metallic mineral } \\
\text { products }\end{array}$ & $2319,2320,2330,2342,2341,2349,2391,2392,3292$ \\
\hline 5 & Manufacture of basic iron and steel & $2411,02412,32421,2422,2429$ \\
\hline 6 & $\begin{array}{l}\text { Manufacture of basic precious and non- } \\
\text { ferrous metals }\end{array}$ & $2441,2443,2452,2531$ \\
\hline 7 & $\begin{array}{l}\text { Manufacture of fabricated metal } \\
\text { products, except machinery and } \\
\text { equipment }\end{array}$ & $\begin{array}{l}2431,2439,2451,2511,2512,2532,2539,2541,2542,2543,2591,3319,2 \\
592,3292,3299,2599,2593,3319\end{array}$ \\
\hline 8 & $\begin{array}{l}\text { Manufacture of machinery and } \\
\text { equipment n.e.c. }\end{array}$ & $\begin{array}{l}2513,3321,2521,2522,2811,2812,2813,2814,2815,2821,2822,2823,2 \\
824,2825,2829,2832,2833,2790,2840,2851,2852,2854,2853,2861,28 \\
62,2863,2864,2865,2543,2866,2869,2550\end{array}$ \\
\hline 10 & $\begin{array}{l}\text { Manufacture of electrical machinery and } \\
\text { apparatus n.e.c. }\end{array}$ & $2751,2759,2892,2710,3321,3731,2732,2733,2721,2740,3295,2790$ \\
\hline 11 & $\begin{array}{l}\text { Manufacture of office, accounting } \\
\text { and computing machinery, including } \\
\text { manufacturing of radio, television } \\
\text { and communication equipment and } \\
\text { apparatus }\end{array}$ & $\begin{array}{l}2621,2622,2632,3321,2610,26 \\
31,2632,2640,2651\end{array}$ \\
\hline 12 & $\begin{array}{l}\text { Manufacture of motor vehicles, trailers } \\
\text { and semi-trailers }\end{array}$ & $2910,2920,2930,3319$ \\
\hline 13 & $\begin{array}{l}\text { Manufacture of other transport } \\
\text { equipment }\end{array}$ & $\begin{array}{l}2722,2945,2941,2942,2943,2944,2950,3011,3317,3012,3031,3032,3 \\
015,3041,3042,3316,3091,3092,3099\end{array}$ \\
\hline 14 & $\begin{array}{l}\text { Manufacture of wood and of products of } \\
\text { wood and cork, including furniture }\end{array}$ & $1610,1621,1622,1623,3319,1629,3292,3101,3329,3102,3104,3103$ \\
\hline 15 & $\begin{array}{l}\text { Manufacture of paper and paper } \\
\text { products, publishing and printing }\end{array}$ & $\begin{array}{l}1710,1721,1722,1731,1732,1733,1741,1742,1749,1811,1812, \\
1813,1821,1822,1830\end{array}$ \\
\hline 16 & Manufacture of rubber products & $2211,2213,2219$ \\
\hline 17 & Manufacture of basic chemicals & $1931,2011,2012,2019,2014$ \\
\hline 18 & $\begin{array}{l}\text { Manufacture of refined petroleum } \\
\text { products and man-made fibers }\end{array}$ & $2021,2022,2031,2032,2033,2040$ \\
\hline 19 & $\begin{array}{l}\text { Manufacture of coke, nuclear fuel and } \\
\text { other chemical products }\end{array}$ & $\begin{array}{l}1910,2019,2123,2449,3812,3822,2013,0210,0220,1932,2029,2051,2 \\
052,2062,2071,2072,2073,2091,2092,2093,2094,2099,2680\end{array}$ \\
\hline 20 & $\begin{array}{l}\text { Manufacture of pharmaceuticals, soaps, } \\
\text { perfumes and toilet preparations }\end{array}$ & $2110,2121,2122,2123,3250,2061,2063$ \\
\hline 21 & Manufacture of plastic products & $2221,2222,2223$ \\
\hline
\end{tabular}




\begin{tabular}{|c|l|l|}
\hline $\begin{array}{c}\text { Code } \\
\text { SNC }\end{array}$ & \multicolumn{1}{|c|}{ Description SNC } & \multicolumn{1}{c|}{ CNAE } \\
\hline 22 & Manufacture of textiles & $\begin{array}{l}1311,1312,1313,1314,1321,1322,1323,1340,1351,1352,1353,1354, \\
1359,1330\end{array}$ \\
\hline 23 & $\begin{array}{l}\text { Manufacture of wearing apparel; } \\
\text { dressing and dyeing of fur }\end{array}$ & $1411,1412,1413,1414$ \\
\hline 24 & $\begin{array}{l}\text { Tanning and dressing of leather; } \\
\text { manufacture of luggage, handbags, } \\
\text { saddlers, harness and footwear }\end{array}$ & $1510,1521,1529,1531,1532,1533,1539,1540$ \\
\hline 25 & Manufcture of coffee products & 1081,1082 \\
\hline 26 & $\begin{array}{l}\text { Processing and preserving of fruit and } \\
\text { vegetables }\end{array}$ & $1031,1032,1033,1061,1062,1063,1064,1065,1069,195,1210,1220$ \\
\hline 27 & $\begin{array}{l}\text { Production, processing and } \\
\text { preservation of meat }\end{array}$ & $1013,1011,1012$ \\
\hline 28 & Manufacture of dairy products & 1051,1052 \\
\hline 29 & Manufacture of sugar & 1071,1072 \\
\hline 30 & Manufacture of vegetable oils and fats & $1041,1042,1043$ \\
\hline 31 & $\begin{array}{l}\text { Manufacture of other food products } \\
\text { n.e.c. }\end{array}$ & $\begin{array}{l}0892,0990,1020,1053,1066,1091,4721,1092,1093,1094,1099,1096,1 \\
111,1112,1113,1121,1033,1122\end{array}$ \\
\hline 32 & $\begin{array}{l}\text { Manufacturing n.e.c. } \\
2660,3102,3250,3321,2651,2670,2733,2652,3211,3220,3232,3230, \\
3240,3319,3299,2092,2229,2399,2829,3092,3212,3299,3329,3831, \\
3832,3939\end{array}$ \\
\hline
\end{tabular}

Source: System of National Account and National Classification of Economic Activities, IBGE. Author's elaboration.

Table A.2 - Variable used, description, and source

\begin{tabular}{c|l|c}
\hline \multicolumn{1}{c|}{ Variable } & \multicolumn{1}{c}{ Description } & Source \\
\hline $\begin{array}{c}\text { Number of } \\
\text { Employees (EMP) }\end{array}$ & $\begin{array}{l}\text { Employees in 12/31 in the reference year : people effectively employed in the } \\
\text { company on the date hereof. }\end{array}$ & PIA Enterprise \\
\hline Exportation (X) & $\begin{array}{l}\text { Dummy variable derived from the target percentage of company sales . Equals } \\
1 \text { if the target percentage for Mercosur and other countries is greater than 0. } \\
\text { Assumes value 0 otherwise. }\end{array}$ & PIA Enterprise \\
\hline Output & $\begin{array}{l}\text { Production value is the sum of production values per informant and product } \\
\text { code. In the aggregate, the variable constructed for each product, follows } \\
\text { the criteria : Production Value = average value of sales ( sales value / quantity } \\
\text { sold ) } x \text { quantity produced. }\end{array}$ & Pia Product \\
\hline
\end{tabular}

Source: PIA-Enterprise and PIA-Product, IBGE. Several years. Authors' elaboration. 
Table A.3 - Multinomial probit estimates of the following Equation 8 (lagged two years)

\begin{tabular}{|c|c|c|c|c|}
\hline Strategy & covariate & $t=2007$ & $t=2008$ & $t=2009$ \\
\hline \multirow{3}{*}{$\begin{array}{l}\text { strategy } 1 \\
\text { only add }\end{array}$} & empl & $\begin{array}{l}0.0084^{\star \star \star} \\
(0.0017)\end{array}$ & $\begin{array}{c}0.0093^{\star \star \star} \\
(0.0016)\end{array}$ & $\begin{array}{l}0,0089^{* \star *} \\
(0,0015)\end{array}$ \\
\hline & $T f p$ & $\begin{array}{c}-0.0032^{\star \star *} \\
(0.0010)\end{array}$ & $\begin{array}{c}-0.0041^{\star * *} \\
(0.0009)\end{array}$ & $\begin{array}{c}-0,0042^{\star * *} \\
(0,0008)\end{array}$ \\
\hline & $X$ & $\begin{array}{l}0.0086^{\star *} \\
(0.0043)\end{array}$ & $\begin{array}{l}0.0114^{\star \star *} \\
(0.0040)\end{array}$ & $\begin{array}{l}0,0191^{* * *} \\
(0,0038)\end{array}$ \\
\hline \multirow{3}{*}{$\begin{array}{l}\text { strategy } 2 \\
\text { only drop }\end{array}$} & empl & $\begin{array}{l}0.0101^{* * *} \\
(0.0017)\end{array}$ & $\begin{array}{c}0.0118^{* * *} \\
(0.0016)\end{array}$ & $\begin{array}{l}0,0093^{* * *} \\
(0,0015)\end{array}$ \\
\hline & $T f p$ & $\begin{array}{c}-0.0038^{\star * *} \\
(0.0153)\end{array}$ & $\begin{array}{c}-0.0043^{\star \star *} \\
(0.0009)\end{array}$ & $\begin{array}{c}-0,0035^{\star * *} \\
(0,0009)\end{array}$ \\
\hline & $X$ & $\begin{array}{l}0.0153^{\star \star \star} \\
(0.0042)\end{array}$ & $\begin{array}{l}0.0146^{\star \star *} \\
(0.0041)\end{array}$ & $\begin{array}{c}0,0152^{* \star *} \\
(0,0041)\end{array}$ \\
\hline \multirow{3}{*}{$\begin{array}{c}\text { strategy } 3 \\
\text { add and drop }\end{array}$} & empl & $\begin{array}{l}0.0015 \\
(0.0030)\end{array}$ & $\begin{array}{c}-0.0075^{\star * *} \\
(0.0028)\end{array}$ & $\begin{array}{c}-0,0148^{* * *} \\
(0,0028)\end{array}$ \\
\hline & $t f p$ & $\begin{array}{l}-0.0034^{* *} \\
(0.0017)\end{array}$ & $\begin{array}{c}0.0006 \\
(0.0015)\end{array}$ & $\begin{array}{c}0,0024 \\
(0,0015)\end{array}$ \\
\hline & $X$ & $\begin{array}{c}0.0193^{\star * *} \\
(0.0073)\end{array}$ & $\begin{array}{l}-0.0115^{*} \\
(0.0070)\end{array}$ & $\begin{array}{l}-0,0021 \\
(0,0071)\end{array}$ \\
\hline & Prob $>$ Wald & 0,0000 & 0.0000 & 0.0000 \\
\hline & № OBS. & 22,989 & 23.549 & 24.343 \\
\hline
\end{tabular}

(Note. Standard errors in parenthesis. Significance: ${ }^{* *} 1 \% .{ }^{* *} 5 \%$ e ${ }^{*} 10 \%$. Authors' computation.) 
Figures confronting annual growth rate of the output of each margin (EXl, EX2 and INT) against business cycle measures: annual growth rate in GDP, in the manufacturing GDP, an in the investment part of GDP.
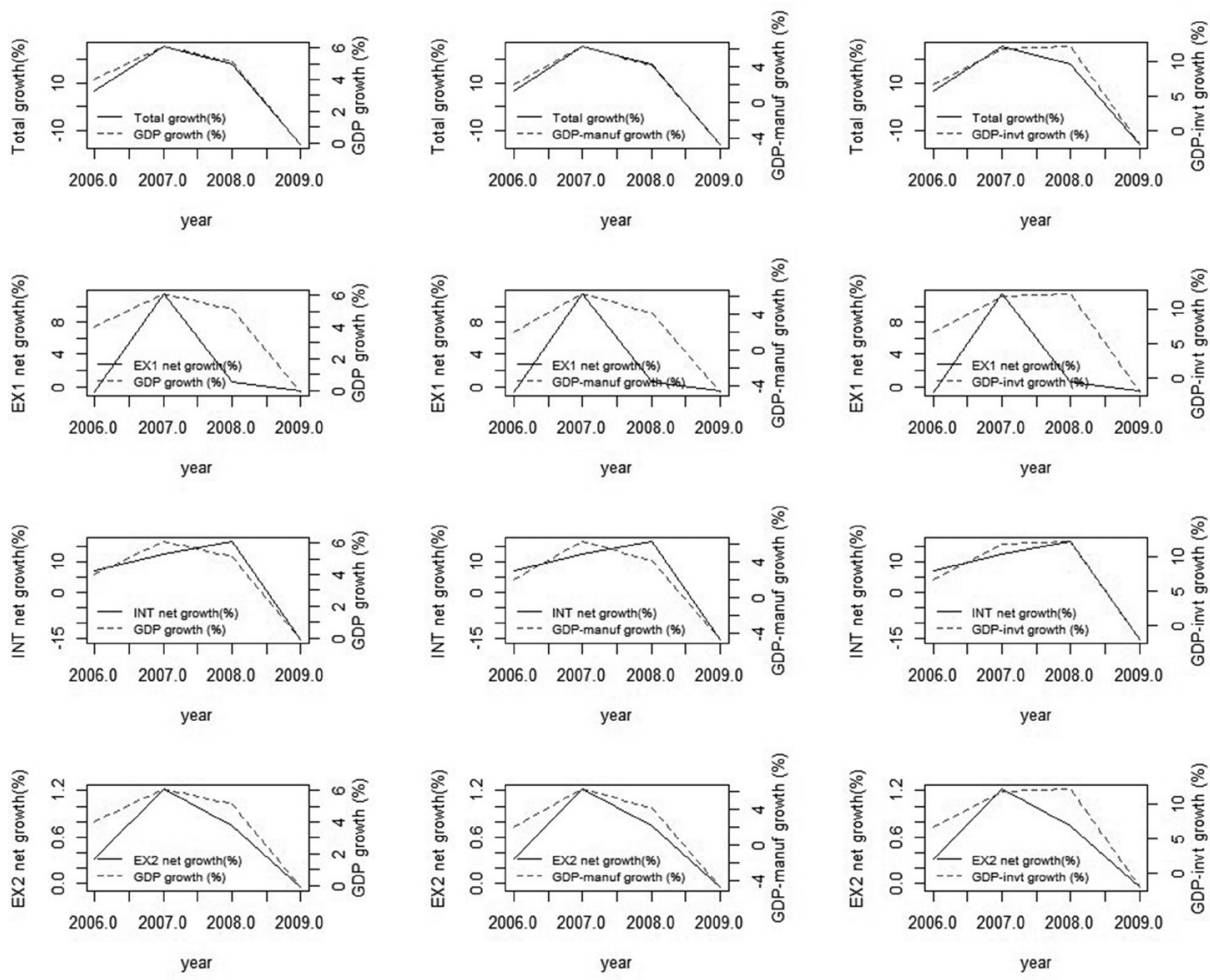

Figure Al. Annual net growth rate of each margin against measures of business cycle growth. Growth is represented in percentage variation. The results from the product decomposition presented in Table 6 are in the left scale of each plot, and each row is reserved for one of the following, in this order: total product growth, extensive margin 1 (firm) net growth, intensive margin net growth, and extensive margin 2 (product) net growth. Each column shows measures of business cycle growth in the following order: GDP, manufacturing GDP, and the investment portion of GDP. Their growth rates are presented in the right scale of each plot. 

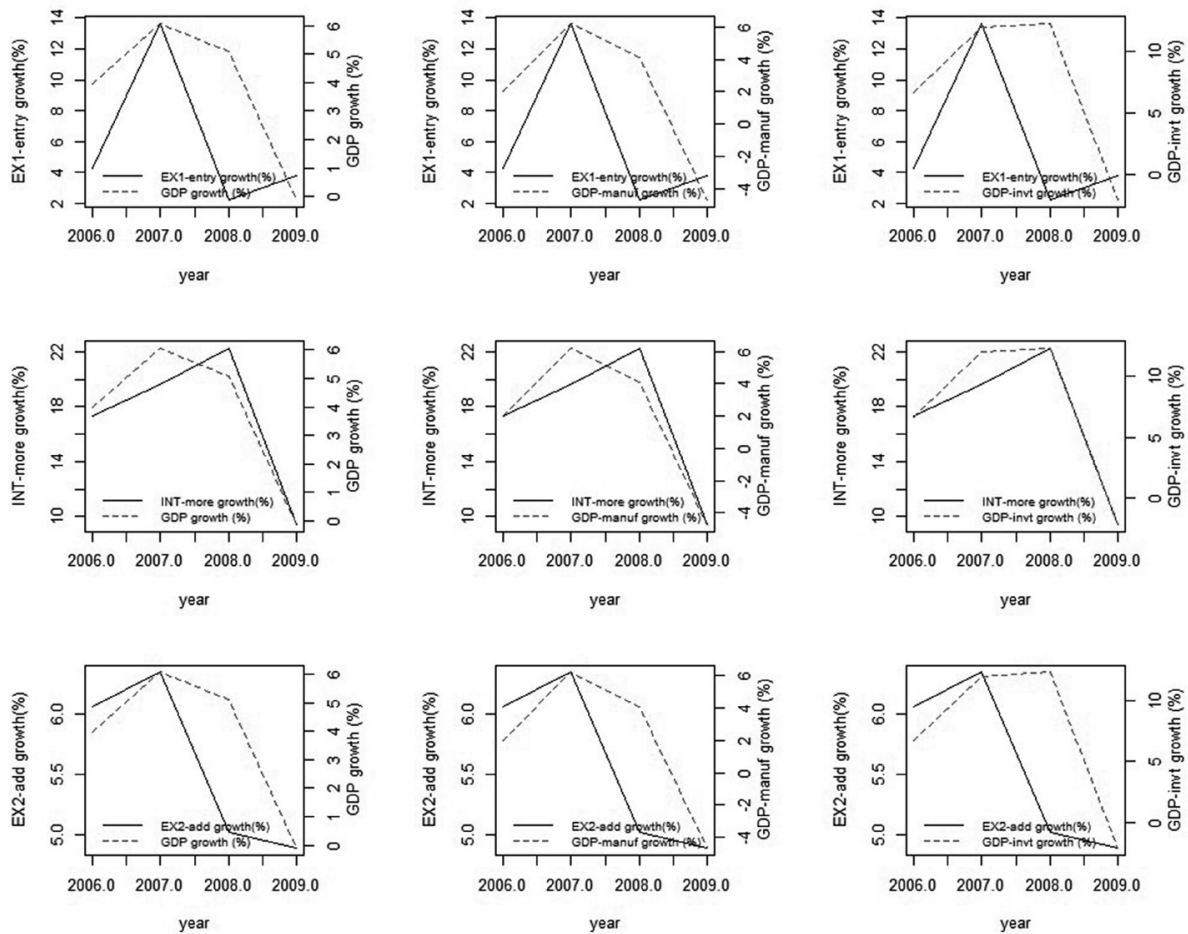

Figure A2. Annual growth rate of the positive effect of each margin against measures of business cycle growth. Growth is represented in percentage variation. The positive effect of the product decomposition presented in Table 6 is in the left scale of each plot, and each row is reserved for one of the following, in this order: extensive margin 1 (EX1-entry), intensive margin (INT-more), and extensive margin 2 (EX2-add). Each column shows measures of business cycle growth in the following order: GDP, manufacturing GDP, and investment portion of GDP. Their growth rates are presented in the right scale of each plot. 

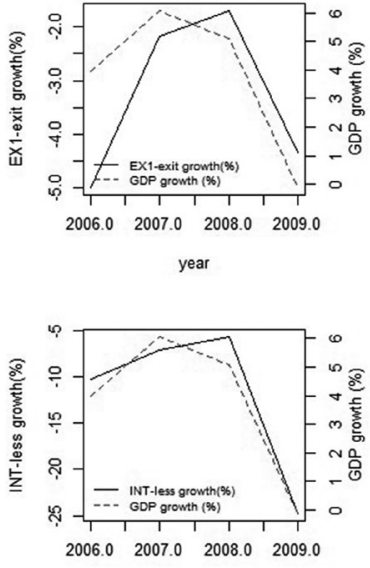

year

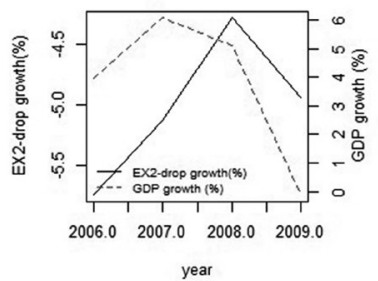

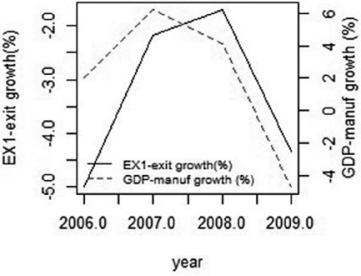

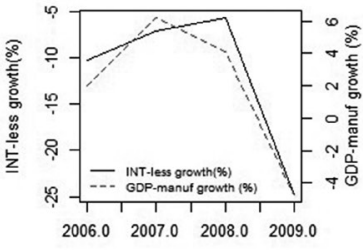

year

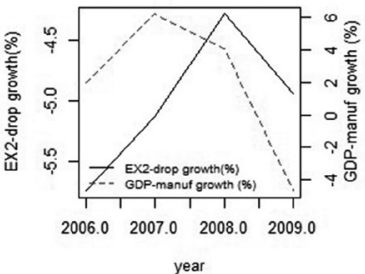

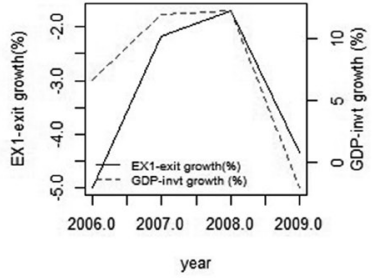
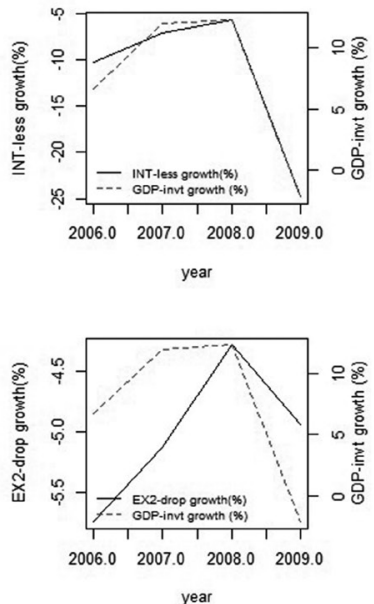

Figure A3. Annual growth rate of the negative effect of margin against measures of business cycle growth. Growth is represented in percentage variation. The negative effect of the product decomposition presented in Table 6 is in the left scale of each plot, and each row is reserved for one of the following, in this order: extensive margin 1 (EXl-exit), intensive margin (INT-less), and extensive margin 2 (EX2-drop). Each column shows measures of business cycle growth in following order: GDP, manufacturing GDP, and investment portion of GDP. Their growth rates are presented in the right scale of each plot. 